\title{
The panorama of miRNA-mediated mechanisms in mammalian cells
}

\author{
Anna Stroynowska-Czerwinska • Agnieszka Fiszer • \\ Wlodzimierz J. Krzyzosiak
}

Received: 24 September 2013 / Revised: 2 December 2013 / Accepted: 30 December 2013 / Published online: 29 January 2014

(C) The Author(s) 2014. This article is published with open access at Springerlink.com

\begin{abstract}
MicroRNAs comprise a large family of short, non-coding RNAs that are present in most eukaryotic organisms and are typically involved in downregulating the expression of protein-coding genes. The detailed mechanisms of miRNA functioning in animals and plants have been under investigation for more than decade. In mammalian cells, miRNA guides the effector complex miRISC to bind with partially complementary sequences, usually within the 3'UTR of mRNAs, and inhibit protein synthesis with or without transcript degradation. In addition to these main mechanisms, several other modes of miRNAmediated gene expression regulation have been described, but their scale and importance remain a matter of debate. In this review, we briefly summarize the pathway of miRNA precursor processing during miRNA biogenesis and continue with the description of the miRISC assembly process. Then, we present the miRNA-mediated mechanisms of gene expression regulation in detail, and we gather information concerning the proteins involved in these processes. In addition, we briefly refer to the current applications of miRNA mechanisms in therapeutic strategies. Finally, we highlight some of the remaining controversies surrounding the regulation of mammalian gene expression by miRNAs.
\end{abstract}

Keywords miRNA - miRNA-mediated regulation of gene expression - Argonaute proteins · miRISC assembly · miRNA binding sites

\author{
Abbreviations \\ Ago \\ ARE \\ CLIP \\ CLASH \\ DGCR8 \\ Exp1 \\ Exp5 \\ Imp8 \\ HuR \\ miRISC \\ miPDC \\ miRNA \\ MRE \\ NES \\ NLS \\ ncRNA \\ P-body \\ PABP \\ PACT \\ pri-miRNA \\ pre-miRNA \\ RBP \\ RLC \\ RNP \\ RRM \\ siRNA \\ TRBP \\ Argonaute \\ AU-rich element \\ UV crosslinking and immunoprecipitation \\ Crosslinking, ligation and sequencing of \\ hybrids \\ DiGeorge syndrome critical region gene 8 \\ Exportin-1 \\ Exportin-5 \\ Importin-8 \\ Human antigen $\mathrm{R}$ \\ miRNA induced silencing complex \\ miRNA precursor deposit complex \\ MicroRNA \\ microRNA response element \\ Nuclear export signal \\ Nuclear localization signal \\ Non-coding RNA \\ Processing body \\ PolyA-binding protein \\ Protein activator of PKR kinase \\ miRNA primary transcript \\ miRNA precursor \\ RNA-binding protein \\ RISC-loading complex \\ Ribonucleic acid protein complex \\ RNA recognition motif \\ Small interfering RNA \\ HIV-1 transactivation response RNA-bind- \\ ing protein
}

\section{Introduction}

A. Stroynowska-Czerwinska · A. Fiszer · W. J. Krzyzosiak ( $\square)$

Department of Molecular Biomedicine, Institute of Bioorganic

Chemistry, Polish Academy of Sciences, ul. Noskowskiego

12/14, 61-704 Poznan, Poland

e-mail: wlodkrzy@ibch.poznan.pl
MicroRNAs (miRNAs) constitute a large family of short, non-coding RNAs (ncRNAs) ( 22 nucleotides long) that 
are common in single-celled eukaryotes, plant and animal cells [1], and have also been found in virus genomes [2,3]. In humans, more than 2,500 miRNAs have already been discovered (collected in the miRBase 20.0 database) [4].

MicroRNAs play a crucial role in the post-transcriptional regulation of gene expression, mostly involving gene silencing. These tiny RNAs are generated in cells through a biogenesis pathway that involves the two-step enzymatic processing of genome-encoded primary miRNA transcripts into short miRNA/miRNA* duplexes. During assembly of the miRNA-induced silencing complex (miRISC), the miRNA/miRNA* duplex is loaded into the Argonaute protein (Ago), and one of the strands (called the "passenger strand") is released and degraded. Consequently, the bound miRNA strand (the "guide strand") guides miRISC to interact with partially complementary sequences in target transcripts (mostly localized within the $3^{\prime}$ UTR) and mainly triggers mRNA deadenylation and degradation or translation inhibition. However, several other mechanisms of gene expression regulation by miRNAs have also been described. The key attribute of miRNA is imperfect base pairing within miRNA/miRNA* duplexes as well as within duplexes formed by the miRNA and its target mRNA. It is estimated that most protein-coding genes are regulated by miRNAs $[5,6]$. Thus, it is not surprising that miRNA deregulation influences cell physiology and triggers numerous pathological states.

In this review, after gathering the relevant information on miRNA biogenesis and miRISC assembly, we focus on the recent understanding of cellular mechanisms of gene expression regulation by miRNAs. This topic still arouses researchers' curiosity because of the controversies around a detailed scheme of miRNA-mediated mechanisms.

\section{Overview of miRNA biogenesis}

The canonical biogenesis pathway of mammalian miRNAs (Fig. 1a) is a two-step (nuclear and cytoplasmic) enzymatic processing of their precursors, which are encoded in the genome (reviewed in [7, 8]). miRNA genes are localized either between protein-coding genes or in their intron elements. Briefly, miRNA genes are typically transcribed by RNA polymerase II [9, 10], or less frequently by RNA polymerase III (Fig. 1.1) [11], to produce long primary miRNA transcripts (pri-miRNA) containing a stem-loop structure. Pri-miRNAs are co-transcriptionally recognized by a large protein complex, called the Microprocessor, the main components of which are the RNase III Drosha and DGCR8 [12-16]. Drosha is responsible for pri-miRNA cleavage - in a process called "cropping"-into 60 nucleotides long, hairpin-structured pre-miRNA (Fig. 1.2) [12, 17]. Next, pre-miRNAs are actively transported from the nucleus into the cytoplasm by Exportin-5 (Exp-5) (Fig. 1.3) $[18,19]$. In the cytoplasm, another RNase III, Dicer, functioning with its protein partners Ago2, TRBP and/or PACT [20-24], recognizes the pre-miRNAs and cleaves them into miRNA/miRNA* duplexes of approximately 22-nucleotide
Fig. 1 miRNA biogenesis in human cells. $a$ The canonical pathway covers 1 pri-miRNA transcription, 2 Drosha cleavage, 3 pre-miRNA export to cytoplasm and 4 Dicer cleavage into 5 the miRNA/miRNA* duplex. $b$ The alternative Drosha-independent biogenesis pathway (mirtron pathway) is indicated by the orange dashed line. See text for more details

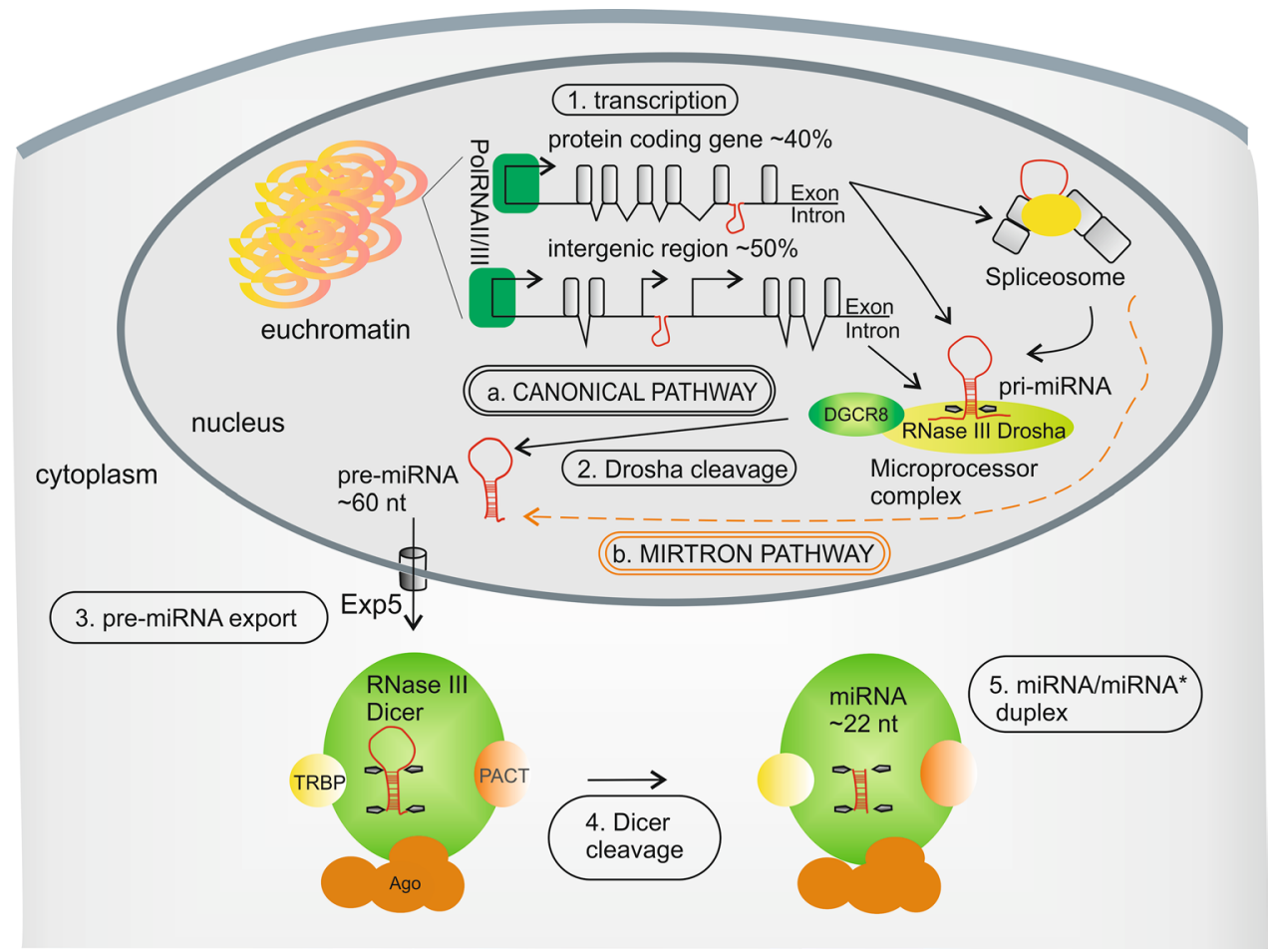


length in a process termed "dicing" [25-28] (Fig. 1.4, 5). In addition to the canonical pathway of miRNA biogenesis described above (Fig. 1a), other pathways exist that are independent of Drosha (wherein miRNAs are generated from pre-miRNA-like introns, called mirtrons) (Fig. 1b) $[29,30]$ or Dicer activity [31-33].

RNase III enzymes (Drosha and Dicer) cleave miRNA precursors imprecisely and generate heterogeneous products that often differ in length [28, 34-36]. These length variants and shifted miRNA sequences are called isomiRNAs (isomiRs) [34]. The isomiRs may vary in their regulation of gene expression because of changes in their target specificity (reviewed in [37]). Some isomiRs, however, may regulate the same targets as the canonical miRNAs $[38,39]$.

Apart from isomiRs, the pool of miRNAs may be varied by the competitive processes of post-transcriptional, nontemplated oligo-adenylation [35, 40-42] or oligo-uridylation [43] at the $3^{\prime}$ termini of pre-miRNAs ([44], reviewed in $[45,46])$. In general, the addition of the U-residues to the $3^{\prime}$ end of RNAs serves as a molecular signal for degradation ([43, 47-49], reviewed in [50]), whereas the extra A-residues tend to increase miRNA stability [41]. Moreover, miRNA precursors might be substrates for adenosine deaminase acting on RNA (ADAR), which converts A-residues into inosine, causing A-to-I RNA editing [51-53]. Inosine pairs with $\mathrm{C}$ - instead of U-residues; hence, it may alter the structure and properties of modified RNA. As a consequence of miRNA precursor sequence modifications by ADAR, several effects may occur, such as miRNA processing inhibition [52, 54, 55], miRISC loading repression [56] or changes in the repertoire of the targeted genes (redirection of targets) ([57], reviewed in [58]).

\section{miRISC assembly}

miRNA/miRNA* duplexes are incorporated into a ribonucleoprotein (RNP) complex - called miRISC - that plays a crucial role in the miRNA-mediated mechanism of gene expression regulation. The core component of miRISC is a protein from the Argonaute subfamily, which is characterized in human cells by the existence of four paralogs: Ago1-4 (reviewed in [59, 60]). Ago proteins consist of four domains: PAZ (binds the $3^{\prime}$ end of the miRNA strand), Mid (binds the $5^{\prime}$-phosphate group of the miRNA), C-terminal PIWI (may possess endonucleolytic activity) and the $\mathrm{N}$-terminal domain (facilitates duplex unwinding) (Fig. 2a). Earlier findings regarding the roles of Ago domains [6165 ] have been recently confirmed by the determination of the three-dimensional structure of human Ago2 alone [66] and in a complex with miR-20a [67]. Among the Ago paralogs, only Ago2 (also called "Slicer") is characterized by
siRNA-induced endonuclease activity toward complementary mRNA sequences $[61,68-70]$ because of the specific structural $[69,71]$ and functional $[72,73]$ features of its PIWI domain, which is similar to that observed in RNase $\mathrm{H}$ [74]. As it was discovered that miRNAs and siRNAs in Drosophila melanogaster cells are sorted into different Ago paralogs ([75-78], reviewed in [79]), it was thought that such sorting may also occur in mammalian cells. However, no miRNA preference for a particular Ago protein paralog has been found by the deep sequencing of miRNAs bound to immunoprecipitated Ago proteins [80]. In addition, according to shotgun proteomic analysis, miRNAs are sorted randomly depending on the abundance of Ago paralogs [81].

Mature miRISC is formed in a multistep assembly process (Fig. 2) (reviewed in [82]). The first step is miRISC loading and the formation of pre-miRISC, when the miRNA duplex is transferred from Dicer to Ago within the RISC loading complex (RLC); this process requires ATP [83-85] and the $5^{\prime}$ phosphate of miRNAs [83]. Interestingly, it has also been shown that miRISC loading might be preceded by miRNA precursor deposit complex (miPDC) formation [86]. The major components of RLC are Dicer, Ago, TRBP and/or PACT (Fig. 2a) [20, 21, 87, 88], and these proteins were shown to participate in strand selection [89-91]. However, the detailed composition of RLC is still under investigation, and it has been suggested that Dicer is not essential in asymmetric miRISC loading [92-94].

It has been shown that either strand from a duplex can be a guide or a passenger strand [95-99]. The selection of a guide strand is thought to depend on the relative thermodynamic stability of miRNA ends, referred to as the "asymmetry rule." The strand with the less stable $5^{\prime}$ end base pairing in the duplex is typically retained by miRISC [100 102]. Moreover, on the $5^{\prime}$ end of the miRNA guide strands, A- and U-residues are much more preferable for the miRISC loading step than are G- or C-residues [103]. Other factors contributing to the efficiency of duplex loading and unwinding are structural features of the miRNA/miRNA* duplexes (e.g., the position of base mismatches) and their sequence composition [84, 85, 104]. Taken together, the differences and changes in the miRNA sequence, such as those observed in isomiRs or edited miRNAs, may affect guide-strand selection [105].

miRISC loading is thought to be continued with an active wedging of the Ago N-terminal domain between duplex strands (Fig. 2b) [106] and duplex unwinding by the Ago PAZ domain (Fig. 2c) [107]. As a result, one strand from a duplex is removed from pre-miRISC and undergoes rapid exonuclease-mediated degradation (Fig. 2d) (reviewed in [46]). Hence, the interaction of Ago proteins with miRNAs $[67,108-110]$ increases miRNA stability in the cell. Similarly, Ago cellular stability is enhanced by miRNA binding $[67,111]$. 


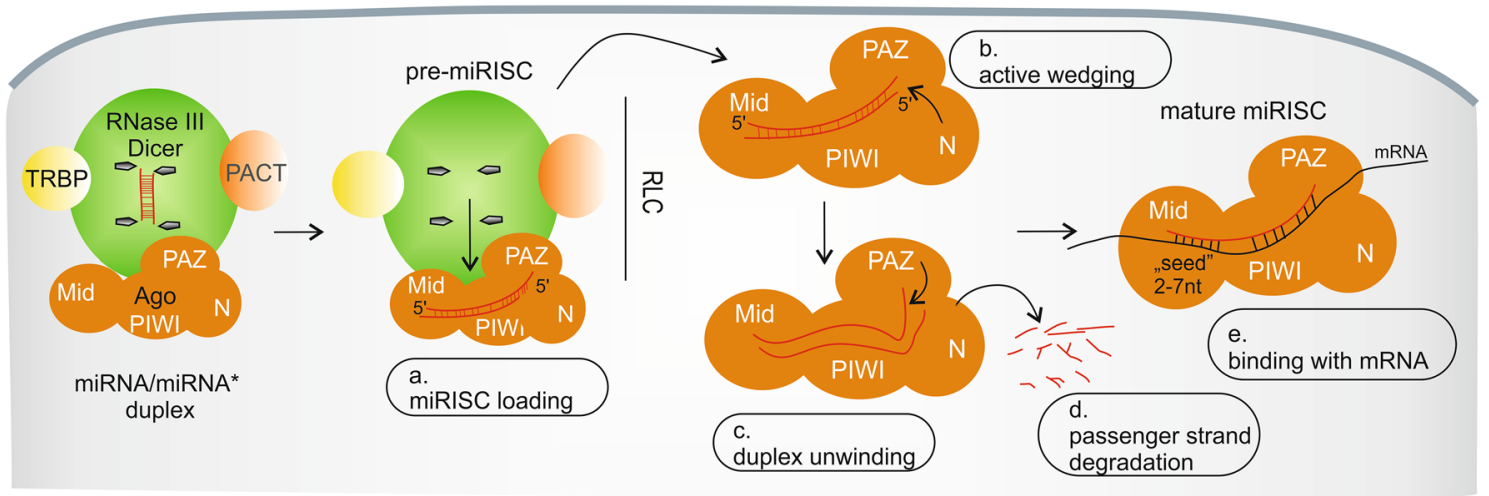

Fig. 2 miRISC assembly in human cells. $a$ The first step is miRISC loading, when the miRNA/miRNA* duplex is transferred from Dicer to Ago in the miRISC loading complex (RLC). $b$ Next, domain $\mathrm{N}$ of Ago actively wedges between miRNA strands and $c$ the PAZ

\section{Alternative miRISC assembly process}

It is commonly held that the Ago:miRNA ratio is approximately $1: 1$ and that the model of miRNA-mediated repression is stoichiometric rather than catalytic. However, Gagnon, Novina and colleagues recently proposed an alternative miRISC assembly [112]. Based on several lines of evidence (e.g., quantitative proteomics and RT-qPCR), the authors demonstrated an at least several-fold cellular excess of miRNA molecules relative to Ago1-4 proteins, and they proved the existence of Ago-free miRNAs [112]. Consistent with this result, other researchers have observed an excess of total miRNAs in comparison to Ago-bound miRNAs [113, 114]. Thus, it might be a general rule that Ago is a limiting factor and that miRNA needs to compete for loading into miRISC.

The proposed alternative RISC assembly pathway implies a catalytic mode of miRNA function, wherein Agos first anneal miRNA guide strands to target transcripts, dissociate from the miRNA-mRNA duplexes, bind another miRNA/miRNA* or miRNA-mRNA duplex, and finally trigger silencing activity (which is, however, less efficient for pre-annealed miRNA-mRNA than for the canonical pathway). This results in miRNA protection and cellular stabilization $[115,116]$ and allows for the association of multiple miRNAs to mRNAs. This pathway may explain the specificity of miRNA binding to sponges and competing endogenous RNAs (ceRNAs) (see Sect. "Modulation of miRNA interactome") [112].

Importantly, the authors demonstrated direct interactions between Ago proteins and pre-annealed miRNA-mRNA duplexes [112]. Their result is not entirely unexpected, as several earlier in vitro studies showed Ago binding to preannealed miRNA-mRNA duplexes [117-119]. The flexible structure of Ago2 [67] may allow its loading with such a domain of Ago unwinds the miRNA duplex. $d$ The passenger strand is removed from miRISC and undergoes rapid degradation. $e$ miRNA within mature miRISC binds with imperfect complementarity to its target sites. See text for more details

complex by appropriate spatial orientation of Ago domains. Together, the studies by Gagnon, Novina and colleagues shed new light on miRNA-mediated mechanisms, but the scale and importance of this alternative mechanism need to be determined.

\section{miRNA-binding sites and their identification}

\section{Characteristics of miRNA-binding sites}

In the canonical pathway, miRISC (guided by the single miRNA strand) finds partially complementary sequences in an mRNA and binds to the transcript (Fig. 2e). However, the detailed mechanism by which miRISC finds the miRNA target site is still unknown. It is thought to be a result of a diffusion-controlled process rather than transcript scanning by miRISCs $[120,121]$. The efficiency of miRISCs binding to their targets was shown to depend on RNA structural factors, such as target sequence accessibility [122-126].

The occurrence of the minimal perfect Watson-Crick pairing between the miRNA and the targeted mRNA sequence is essential for miRNA-mediated gene expression regulation, at least in the specific region called the "seed" region (2-7 nucleotides at the $5^{\prime}$ end of the miRNA) (Fig. 2e) [127, 128]. Apart from the canonical pairing site, the rest of the sequence (the $3^{\prime}$ end) may form an additional matching region called the $3^{\prime}$-supplementary or $3^{\prime}$-compensatory site $[129,130]$, but nucleotides $9-12$ tend to be mismatched to prevent Ago2-mediated cleavage of mRNAs [129]. The importance of "seed" pairing is well proven for the regulatory functions of miRNAs [67, 129]; thus, isomiRs with shifted $5^{\prime}$ ends may regulate different targets because of the changed "seed" sequence $[35,39,96]$. However, recent global analyses showed that only $<40 \%$ 
miRNA-target interactions involve uninterrupted WatsonCrick base pairing in the "seed" region [131]. Moreover, several non-canonical interactions within the "seed" region were found to be functional [131-134], which suggests that miRISC may be more flexible in target binding than previously anticipated.

Until recently, functional miRNA-binding sites were thought to be usually localized within the $3^{\prime}$ UTR [129] but might also be present within the coding sequence (CDS) [135-139] and the 5'UTR [140-142]. Surprisingly, the results from genome-wide analyses of miRNA-binding sites, performed by the Darnell, Tuschl, Sharp and Tollervey groups, clearly indicate that a substantial fraction of miRNAs interacts with sequences localized within the CDS (Fig. 3) [131, 143-145]. This suggests that the CDS may be widely targeted by miRNAs and that these miRNA target sequences might be underestimated. However, the functionality of the miRNA-binding sites in the $5^{\prime} \mathrm{UTR}$ and CDS is considered to be lower than that of the $3^{\prime}$ UTR as miRISC may not resist the collision with the scanning small ribosomal subunit and rapidly translocating ribosomes [146].

Importantly, the efficiency of miRNA-mediated gene expression regulation may depend on the number of miRNA-binding sites within regulated targets [147, 148] and the distance between these sites [147, 149-151]. The more target sites that are present on the transcript, the higher the observed silencing efficiency. This phenomenon is likely a result of cooperative interactions between neighboring bound miRISCs [128, 147, 149, 151].

Taking the rules for miRNA binding to transcripts together, the most efficient target regulation involves multiple "seed"-containing interactions within the 3'UTR of an mRNA. Nevertheless, many non-canonical interactions were identified, and their functionality remains to be established.

Prediction and identification of miRNA-binding sites

The reliable identification of transcripts that are regulated by miRNAs is essential for unraveling the specific cellular functions of miRNAs (reviewed in [152, 153]). Thus, several algorithms have been developed for miRNA target predictions including miRANDA [154], RNAhybrid [155, 156], PicTar [157], TargetScan [158] and PITA [159] (compared in $[130,160])$. These algorithms take into account i.a. the relevance of "seed" pairing, the sequence conservation among species, the free energy of miRNA-mRNA binding and target site accessibility. In addition, new algorithms, for example, miRco (predicting binding sites in a cooperativity-permitting distance) [151] and MREdictor (accounting for protein-binding sites within miRNA target sequence) [161], have been described.

The predicted miRNA-mRNA interactions may contain many false positives; thus, the functionality of such interactions needs to be verified experimentally. The methods for validating miRNA targets include the use of miRNA inhibitors or miRNA mimics in dedicated gene-specific expression assays, usually luciferase reporter assays, or in high-throughput assays (reviewed in [162, 163]). Global methods developed in recent years enabled the analysis of a pool of Ago-bound miRNAs [80, 164] and Ago-bound transcripts [143-145] in mammalian cells. The basis for these analyses is the use of UV crosslinking and immunoprecipitation (CLIP) followed by deep sequencing and bioinformatic mapping of the reads ([165, 166], reviewed in [167]). Nevertheless, in global analyses of the RNA interactome,

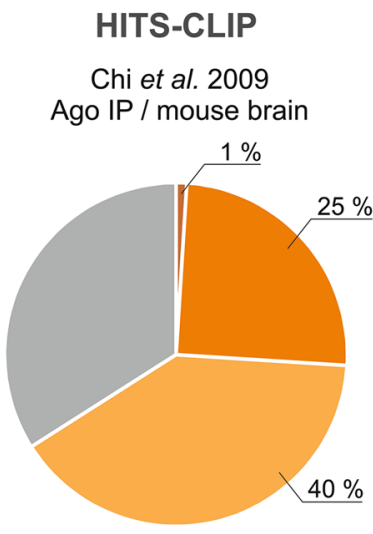

PAR-CLIP

Hafner et al. 2010 Ago IP / HEK cells

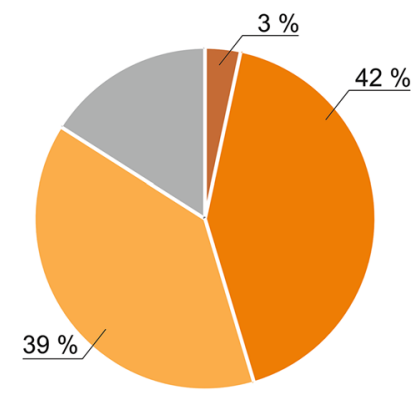

5'UTR

\section{CLASH}

Helwak, Kudla et al. 2013 Ago1 IP / HEK cells

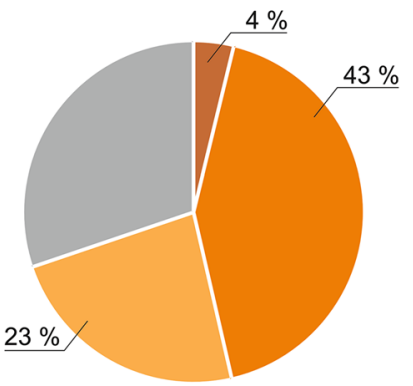

Fig. 3 The miRNA-binding site distribution in the mammalian transcriptome as revealed by different global analyses of RNAs immunoprecipitated with Ago proteins. The method, reference and experimental basics are given for each analysis. The main miRNA targets are found in mRNAs and were mapped to $5^{\prime} \mathrm{UTR}$, CDS and $3^{\prime} \mathrm{UTR}$ regions (approximate shares of these reads are given in the pie charts). A group of "other" reads contains different non-coding RNAs: pseudogenes, intronic and intragenic sequences 
it is challenging to extract a single specific miRNA-mRNA interaction from the whole data set. More recently, a novel method of crosslinking, ligation, and sequencing of hybrids (CLASH) was developed [168] and applied for the highthroughput identification of miRNA-target pairs [131]. CLASH allowed the identification of $\sim 18,000$ high-confidence miRNA-target interactions (via Ago1) in human cells and provided more precise insights into the miRNA interactome than were possible previously (Fig. 3).

\section{Modulation of the miRNA interactome}

Target regulation by miRNAs can be additionally controlled by modulation of miRNA-binding sites. Specific factors may increase or decrease the number of miRNA target sites and block or facilitate miRNA binding. For instance, the presence of several alternative polyadenylation sites (PAS) may give rise to transcripts that differ in the length of their $3^{\prime}$ sequence (reviewed in $[169,170]$ ) and thus the number of miRNAbinding sites. The selection of the functional PAS may depend on the developmental stage of the cells or the tissue specificity. For example, miR-206 supresses the expression of Pax3 in limb muscle stem cells but not in diaphragm muscle stem cells, because in the latter cells $3^{\prime} \mathrm{UTR}$ of the Pax 3 transcript is shortened that results in loosing miR-206-binding sites [171]. Furthermore, specific RNA-binding proteins (RBPs) (e.g., Dnd1 or Pumilio) may possess binding sites overlapping with miRNA binding sites, causing them to interfere with one another [172, 173]. Moreover, post-transcriptional modification of the transcript, i.a., deamination of A residues, may create novel miRNA-binding sites [174] or eliminate miRNA:mRNA recognition [175]. In addition, transcripts that share microRNA response elements (MREs) may co-regulate each other through the competitive binding of miRNAs [176, 177]. To address this issue, a hypothesis regarding competing endogenous RNAs (ceRNAs) was proposed. It suggests that both coding and noncoding RNA may crosstalk through MREs with miRNAs [178] and suppress the regulatory functions of miRNAs by sequestering them and affecting the pool of miRNAs available for target binding [179-181]. Thus far, different types of long non-coding RNAs (lincRNAs) [182] have been described as miRNA antagonists, including circular RNAs (circRNAs) [183, 184], pseudogenes [185] and viral RNAs [186]. Moreover, many other types of RNAs (e.g., rRNA and tRNA) were found to interact with miRNAs $[131,143]$, but the relevance of these binding sites remains to be determined.

\section{Variations in miRNA-mediated mechanisms}

The miRISC binds to a targeted mRNA sequence and typically downregulates its translation mainly via mRNA deadenylation (Fig. 4b), which causes transcript decay (Fig. 4d, e) [187-189], or via translation inhibition (Fig. 4a) [190-192]. However, the detailed composition of miRISC, as well as its regulatory function, is still under investigation. The main proteins currently known to be involved in miRNA-mediated mechanisms are listed in Table 1.

It is postulated that at least two miRISC components, interacting with each other, are crucial in miRNA-mediated mechanisms: Argonaute (see the Sect. "miRISC assembly") and conserved GW182 protein family members. GW182 is the main component of processing bodies (P-bodies or GW-bodies; see the Sect. "Transcript deadenylation and degradation"). Three paralogs of the GW182 protein (TNRC6A-C) are expressed in vertebrate cells (reviewed in [193]). Characteristic features of the GW182 protein family include many glycine-tryptophan or tryptophan-glycine repeats (GW/WG repeats) [194], the number and localization of which vary among family members. The N-terminal GW-repeats comprise multiple independent Ago-binding sites, called Ago hooks ([195198], reviewed in [199]), whereas C-terminal GW repeats are the binding platform for the subunits of deadenylase complexes: NOT1 [200-202] and PAN3 [200]. Structurally, the vertebrate and insect proteins are composed of three main parts: the N-terminal Ago-binding domain, the central ubiquitin-associated (UBA)-like domain and the $\mathrm{C}$-terminal silencing domain with the non-canonical RNA recognition motif (RRM), which is most likely responsible for the protein-protein interactions [203]. The silencing domain is believed to trigger gene silencing by both translational repression and mRNA decay [204-207]; it contains a PAM2 motif that interacts with the PABC domain of the polyA-binding protein (PABP). This motif allows GW182 to function as a link between Ago and other proteins (Table 1).

Translation regulation: inhibition and rare upregulation

The first postulated miRNA-mediated mechanism was translation inhibition without transcript downregulation [190-192]. Protein synthesis inhibition is likely cap (m7G)-dependent, because the lack of a natural cap [208] or the presence of its analogs impairs this process [209]. However, some researchers have reported a mechanism of cap-independent, IRES-driven translation repression [210, 211]. Additionally, the translational step that is inhibited by miRNAs remains a matter of debate. The results of ribosome profiling experiments suggest the formation of both light, monosome- $[208,212]$ and heavy, active polysomecontaining fractions $[213,214]$ on mRNA during miRNAmediated gene silencing. These findings indicate that protein synthesis regulation may occur at either translation initiation (Fig. 4a, 1-2) or elongation (Fig. 4a, 3-5). 


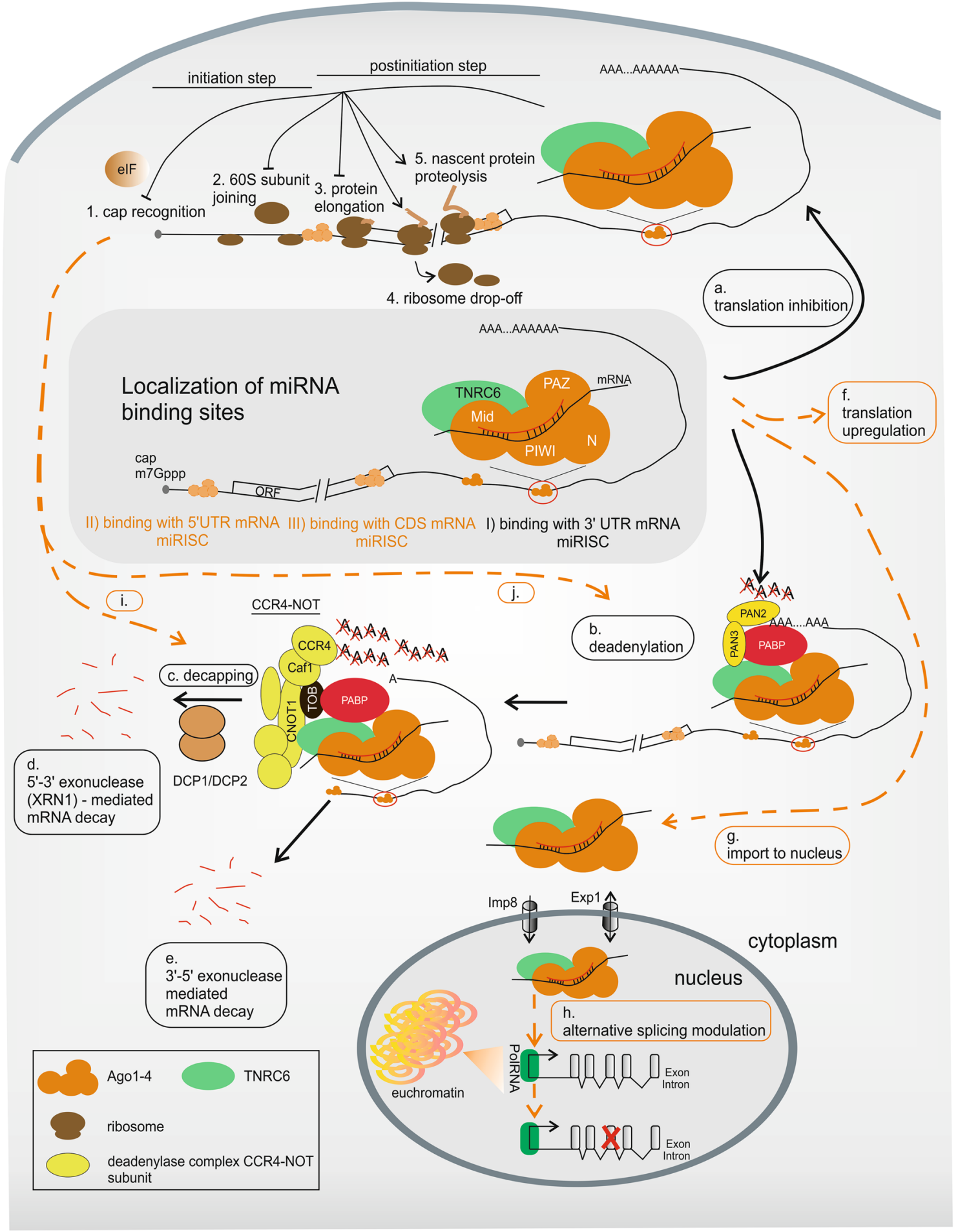

Fig. 4 miRNA-mediated mechanism of gene expression regulation in human cells. Mature miRISC binds miRNA target sites localized $I$ mostly within the $3^{\prime}$ UTR but also (indicated in orange) II in the $5^{\prime} \mathrm{UTR}$ or III in the CDS. There are two main pathways of miRNAmediated mechanisms of gene expression regulation: $a$ translation inhibition either on initiation $(1,2)$ or at a post-initiation step $(3-5)$ and $b$ deadenylation followed by $c$ decapping and $d, e$ mRNA decay However, some less well-known alternatives, indicated by dashed orange lines, have been described: $f$ translation upregulation, $g$ import into the nucleus and $h$ alternative splicing modulation, $i$ decapping followed by translation inhibition and $j$ deadenylation followed by translation inhibition. See text for more details 


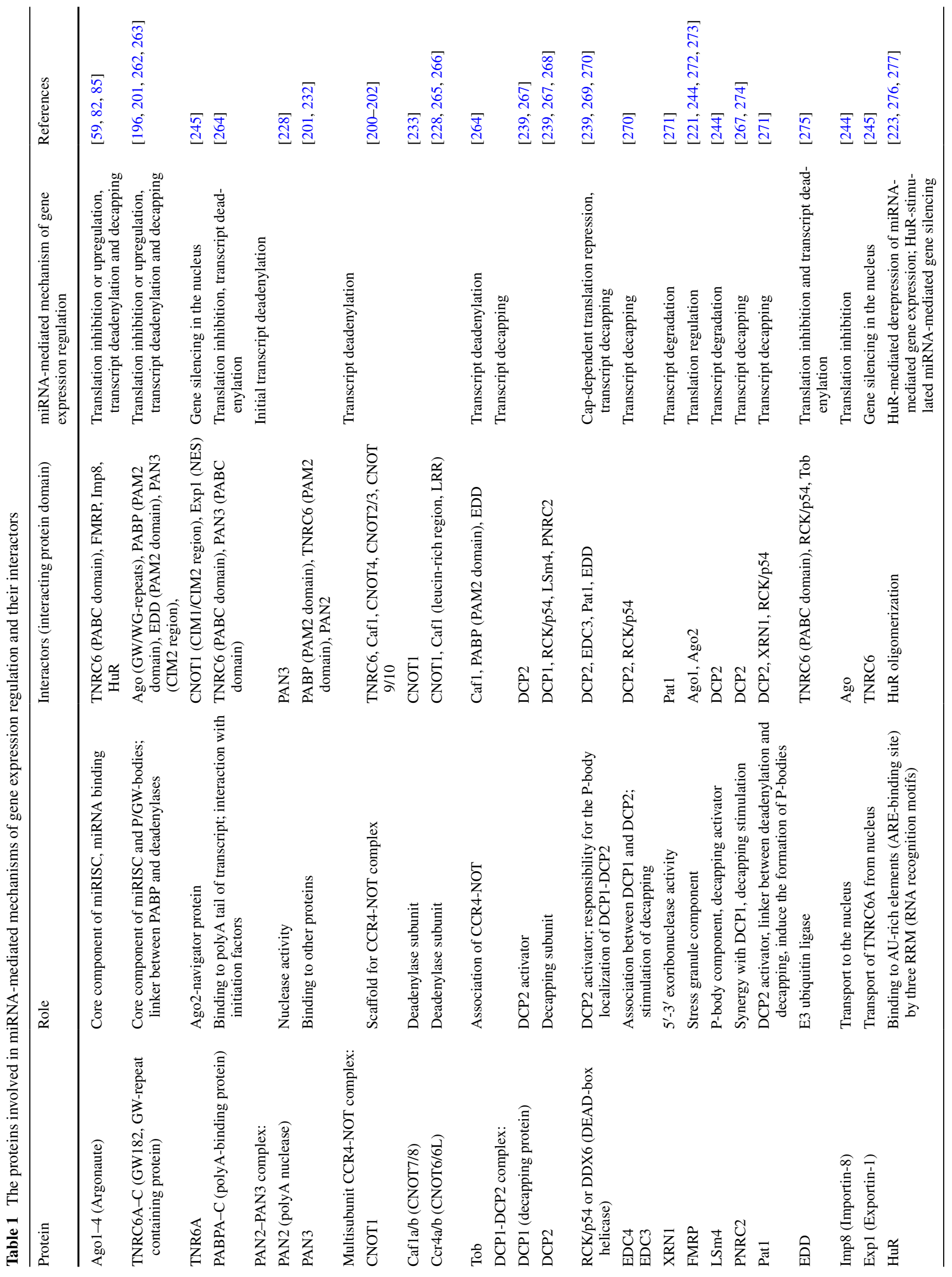


The blockage of translation initiation may be caused by defects in ribosome recruitment to the regulated mRNA. One explanation for such a blockage is the impairment of cap recognition resulting from the interference of miRISCassociated proteins with translation initiation factors (Fig. 4a, 1) [209, 215] or from the interaction of miRISC with the $5^{\prime}$ cap structure $[212,216]$. The second possibility is the repression of $60 \mathrm{~S}$ ribosome subunit joining (Fig. $4 \mathrm{a}$, 2) $[217,218]$. In contrast, the formation of polysomal fractions during miRNA-mediated silencing suggests an opportunity to inhibit protein synthesis at the post-initiation level $[210,213,214]$. This most likely involves a block in elongation (Fig. 4a, 3) [213], ribosome drop-off (Fig. 4a, 4) [210] or nascent protein proteolysis (Fig. 4a, 5) [191, 214]. However, the significance of these latter mechanisms seems to be rather limited.

According to the existing knowledge, translation initiation is extensively regulated (i.a., during mRNA circularization, cap recognition, initiation complex formation, $40 \mathrm{~S}$ scanning); thus, intuitively, it may be easier to affect any of these regulatory points. Therefore, we favor miRNA-mediated translation inhibition at the initiation step rather than during elongation. Surprisingly, in the output of miRNA interactome revealed by CLASH, the most numerous and highly reproducible non-mRNA chimeras were formed with the $18 \mathrm{~S}$ and $28 \mathrm{~S}$ rRNAs, suggesting miRNA interactions with ribosomes [131]. This is consistent with previous evidence for the association of miR-206 with nuclear pre-ribosomes and cytoplasmic ribosomes [219] and for the presence of ribosomal proteins in the Ago-associated protein fraction [220]. Such an interaction may imply that miRISCs directly interfere with ribosomes and trigger translation inhibition.

Interestingly, under certain cellular conditions, such as cell cycle arrest in G0/G1, cellular stress or nutrient shortage, miRNAs may also induce translation upregulation (Fig. 4f) [221, 222]. For instance, miR-10a interacts with the $5^{\prime}$ UTR of mRNAs encoding ribosomal proteins and causes an increase in translation [141]. Another example is miRNA-mediated translation activation, which is associated with Ago and AU-rich elements (AREs) [221]. One of the ARE-binding proteins, HuR, is able to derepress miRNA-mediated translation inhibition (Table 1) [223]. Moreover, miRNA binding may also trigger increased ribosome loading and therefore upregulate protein synthesis [224].

\section{Transcript deadenylation and degradation}

More recently, transcript deadenylation was demonstrated to be a widespread effect of miRNA activity (Fig. 4b) [188] and is suggested to lead to mRNA degradation (Fig. 4d, e). In specific cases, mRNA cleavage by miRISC was also reported [225, 226]. Bartel and colleagues have shown that most (at least $84 \%$ ) of the decreased protein production caused by miRNAs is an effect of reduced mRNA levels [189]. Thus, most of the research on miRNA-mediated mechanisms currently focuses on the issue of mRNA decay. Apart from Ago and GW182, several other proteins (e.g., PABP, deadenylase complexes PAN2-PAN3 and CCR4NOT) have been demonstrated to be crucial components of the deadenylation mechanism (Table 1) (reviewed in [227]). It was proposed that deadenylation in human cells occurs in two sequential phases. First, PAN2 (the catalytic subunit of the PAN2-PAN3 complex) mediates the initial rapid deadenylation; then, two subunits of the CCR4-NOT complex, CCR4 (CNOT6/6L) and Caf1 (CNOT7/8), are most likely responsible for shortening the polyA tail [228, 229].

The mechanism of deadenylation is being carefully studied, including the structural aspects of the protein-protein interactions, to create a detailed model of deadenylationdependent repression and better understand this process (reviewed in [230, 231]). It has been demonstrated previously that PAN3 [232] and TNRC6 possess a PAM2 motif, which enables them to interact directly with PABP (Fig. 4b) [200, 233, 234]. In addition, TNRC6 recruits PAN3 (Fig. 4b) [200, 201]. The interaction of the PAN2PAN3 complex with PABP likely facilitates deadenylation. Conversely, no subunit of the large deadenylase complex CCR4-NOT contains a PAM2 motif, though this protein complex may cooperate with the TOB protein, which contains such a motif (Fig. 4b). In addition, CNOT1 (a scaffold and the large subunit of CCR4-NOT) interacts with TNRC6 (Fig. 4b) (reviewed in [235]).

Deadenylation may be continued by transcript degradation either via decapping by DCP1-DCP2 complex activity (Fig. 4c) and the $5^{\prime}$-to-3' exonuclease XRN1 (Fig. 4d) or by $3^{\prime}$-to- $5^{\prime}$ cytoplasmic exonucleases (Fig. 4e) (Table 1) (reviewed in [236]). It has been shown that decapping factors are directly recruited by PAN2-PAN3 and CCR4-NOT [200-202]. This binding might be facilitated by the high concentration of these proteins in P bodies. These cellular compartments are cytoplasmic foci where miRNAs and miRNA targets, together with proteins involved in deadenylation and decapping, are found. Moreover, translationally repressed mRNAs are stored and degraded in the P bodies ([237], reviewed in [238]). Interestingly, Izaurralde and colleagues suggested that miRISC also promotes deadenylation-independent decapping because of the indirect interaction of decapping factors with miRISC (Fig. 4i) [239].

Translation repression may precede mRNA deadenylation and degradation

According to the previous suggestions [208, 216, 233] and recently published reports [234, 240, 241], 
translation regulation and mRNA decay following deadenylation are thought to be directly connected (Fig. 4j). Filipowicz and colleagues have reported that translation repression may precede deadenylation and mRNA decay [240]. Bushell and colleagues confirmed this observation and showed that translational inhibition (caused by the inhibition of initiation factor eIF4A2 binding) is the primary event required for mRNA degradation [241]. Izaurralde and colleagues conducted functional assays on D. melanogaster and human cells, which indicated that miRNA-mediated translational repression and degradation are mechanistically linked through the interactions of GW182 proteins with PABP and deadenylases [234]. It could be expected that this link between translation inhibition and deadenylation might function to modulate transcript turnover.

miRNA activity in the nucleus

Following the trend of epigenetic research, increasing attention has recently been paid to short non-coding RNAs (i.a., siRNA, miRNA) that may regulate transcription (reviewed in [242, 243]). Interestingly, Meister and colleagues identified heterogeneous nuclear ribonucleoprotein particles, i.e., hnRNP-U and hnRNP-F, among proteins immunoprecipitated with Agos [220], which indicates the possible interaction of these proteins with Agos in the nucleus. Moreover, it has been shown that importin-8 (Imp8) is an essential protein factor required for the miRNA-mediated regulation of gene expression and for the localization of Ago2 in the nucleus (Table 1) [244].

Surprisingly, a recently published work described a TNRC6A paralog that possesses both a nuclear localization signal (NLS) and nuclear export signal (NES) [245]. These sequences allow TNRC6A to function as a navigator for Ago proteins into and out of the nucleus by Exportin-1 (Table 1) [245]. Also, Dicer was found in the nucleus [246], and a non-canonical NLS was recently identified within its C-terminal region [247]. However, the role of Dicer in the nucleus remains unclear.

Taken together, these results strongly suggest the importance of Ago protein localization and activity in the nucleus (Fig. 4g). Thus far, Ago complexes in the nucleus are thought to play a major role in the RNA-mediated alternative splicing process involving chromatin remodeling (Fig. 4h) [248, 249]. In agreement with these observations, high-throughput analysis of the miRNA interactome by CLASH identified targets mapped to splice junctions [131]. Moreover, the deadenylase complex CCR4-NOT, interacting with miRISC, is proposed to play an auxiliary role in transcription elongation [250]. Nevertheless, the detailed mechanism of miRNA involvement in transcription regulation is poorly understood.
Based on the results described above and the widespread effect of chromatin remodeling on the regulation of gene expression, we anticipate that future research will reveal more examples of miRNAs participating in nuclear processes.

\section{Implications of miRNA-mediated mechanisms for therapy}

The complexity of the abundant miRNA-mRNA interactions arises from the fact that one mRNA may harbor binding sites for numerous different miRNAs [149, 251]; also, one miRNAs may be involved in regulating the expression of many transcripts. Thus, aberrant miRNA expression, either up- or downregulation, impairs cell homeostasis and is associated with a wide variety of human disorders (collected in the Human miRNA Disease Database) [252].

The precise modulation as well as reversal of such miRNA alterations is not only a challenge for fundamental research but also a promising strategy for miRNA-based therapy. Such therapy might be achieved by introducing miRNA blockers (sponges, inhibitors, anti-miRNAs) or miRNA mimics (artificial miRNAs) that may target dysregulated miRNA pathways. Recently, an efficient miRNAbased drug against hepatitis C (miRavisen, anti-miR-122) was tested in the second phase of clinical trials [253, 254].

The knowledge of miRNA-mediated mechanisms is also very useful for designing improved RNAi-based therapeutic tools. A popular trend is the use of pri-/pre-miRNA-based shRNA expression cassettes for more efficient and longer lasting gene silencing (reviewed in $[255,256])$. Another example is the use of miRNA-like siRNAs for the downregulation of genes responsible for Huntington's disease (HD) and spinocerebellar ataxia type 3 (SCA3), as recently described by Corey and colleagues as well as our group [257-260]. The principle of this approach is to directly target the mutation site, i.e., the expanded CAG repeat tract in the transcript of the mutant gene. The siRNAs that have been developed imitate miRNAs, as they form mismatched interactions with the target sequence and possess multiple neighboring binding sites on the mutant transcript. Importantly, the normal allele of the implicated transcript, as well as transcripts of other genes containing short CAG repeat tracts that are thought to provide only a single binding site for RISC, is much less efficiently silenced by miRNA-like siRNAs. Hence, the multiple RISC-binding sites allow for very efficient silencing of the mutant transcript, which might result from the cooperative action of adjacent miRISCs on the expanded CAG tract [260, 261]. It is worth highlighting that the multiple binding sites for the CAG repeat-targeting siRNAs are localized within the transcript CDS. Analyses of the silencing mechanism of these 
siRNAs revealed that translational inhibition is involved rather than Ago2-mediated mRNA cleavage or mRNA degradation, and a crucial role for the Ago 2 and TNRC6A-C proteins was demonstrated [261].

\section{Conclusions and future perspectives}

Although important advances have been made in miRNA research over the past several years, we still remain unable to profoundly comprehend the miRNA-based cellular processes. Numerous detailed questions remain unanswered, and among them are the following: Which factor is most important in determining the effect of miRNA activity? Is it the position of miRNA/mRNA mismatches? Is it the localization and number of miRNA-binding sites? How miRNAs within miRISCs find their binding sites on the transcript sequence is also poorly understood. Furthermore, it is not clear whether we already know all of the critical factors involved in mature miRISC formation and miRNA functioning in the cell.

As new mechanisms (e.g., alternative RISC assembly, transcriptional regulation, nuclear activity) are discovered, the question of whether they are widespread is of great importance. The results indicate that there is no single pathway of miRNA-mediated regulation common to all miRNAs in human cells. Moreover, the contradictory findings concerning the specific steps of translation that are inhibited via miRNAs remain very controversial. It seems that the variety of systems used to perform miRNA research might strongly contribute to the observed discrepancies.

Nevertheless, in agreement with recent results, the prevailing opinion concerning miRNA-mediated mechanisms is that silencing is mainly caused by transcript decay, which follows mRNA deadenylation. Thus, much effort has been made to identify the proteins involved in this process as well as interactions that take place between these proteins. The relevant information is collected in Table 1 . This table presents multiple direct protein-protein interactions and suggests many indirect associations; however, it is likely that other proteins are also involved. We still do not know much about the stoichiometry of these interactions or how miRNA and transcript binding by miRISC influences protein interactions within this complex.

More generally, we consider that multiple miRNAmediated mechanisms may operate in cells depending on, i.e., the nature of the miRNA-mRNA interactions and the type of cell or its physiological state. In a single cell, there are abundant interactions among mRNAs, miRNAs and their variants as well as various protein factors competing for interactions with miRISC. Therefore, the notion that the specific miRNA/mRNA duplex may activate not one but two or more different silencing mechanisms concomitantly (e.g., deadenylation and translation inhibition) cannot be ruled out.

Over the last few years, a growing body of evidence has formed that supports the existence of non-canonical miRNA-binding sites, in a sense of: miRNA pairings with targets, localization within the CDS and interactions with noncoding RNAs. This notion needs to be implemented into next-generation MRE prediction algorithms and taken into account in analyses of relevant deep sequencing data. Also worth highlighting is the fact that miRNA binding to non-canonical targets can modulate the levels of miRNAs and their canonical functions. Together, it is also likely that additional new functions of miRNAs await to be disclosed.

Acknowledgments The authors would like to thank Edyta Koscianska and Julia Starega-Roslan for their critical comments on the manuscript. This work was supported by: the Polish Ministry of Science and Higher Education (N N301 569340 to WJ.K., "Diamond grant" Programme DI 2011027841 to A.SC, IP2012032472 to A.F.), European Regional Development Fund within Innovative Economy Programme (POIG.01.03.01-30-098/08 to WJ.K.) and the National Science Centre (2011/03/B/NZ1/03259 to WJ.K.); A.SC. was a scholarship holder within the project "Scholarship support for PhD students specializing in majors strategic for Wielkopolska's development," Sub-measure 8.2.2 Human Capital Operational Programme.

Conflict of interest The authors declare no conflict of interests.

Open Access This article is distributed under the terms of the Creative Commons Attribution License which permits any use, distribution, and reproduction in any medium, provided the original author(s) and the source are credited.

\section{References}

1. Carthew RW, Sontheimer EJ (2009) Origins and mechanisms of miRNAs and siRNAs. Cell 136:642-655. doi:10.1016/j. cell.2009.01.035

2. Kaul D, Ahlawat A, Gupta SD (2009) HIV-1 genome-encoded hiv1-mir-H1 impairs cellular responses to infection. Mol Cell Biochem 323:143-148. doi:10.1007/s11010-008-9973-4

3. Meshesha MK, Veksler-Lublinsky I, Isakov O et al (2012) The microRNA transcriptome of human cytomegalovirus (HCMV). Open Virol J 6:38-48. doi:10.2174/1874357901206010038

4. Kozomara A, Griffiths-Jones S (2011) miRBase: integrating microRNA annotation and deep-sequencing data. Nucl Acids Res 39:D152-D157. doi:10.1093/nar/gkq1027

5. Bartel DP (2004) MicroRNAs genomics, biogenesis, mechanism, and function. Cell 116:281-297. doi:10.1016/ S0092-8674(04)00045-5

6. Friedman RC, Farh KK-H, Burge CB, Bartel DP (2009) Most mammalian mRNAs are conserved targets of microRNAs. Genom Res 19:92-105. doi:10.1101/gr.082701.108

7. Krol J, Loedige I, Filipowicz W (2010) The widespread regulation of microRNA biogenesis, function and decay. Nat Rev Genet 11:597-610. doi:10.1038/nrg2843

8. Libri V, Miesen P, van Rij RP, Buck AH (2013) Regulation of microRNA biogenesis and turnover by animals and their viruses. Cell Mol Life Sci 70:3525-3544. doi:10.1007/ s00018-012-1257-1 
9. Cai X, Hagedorn CH, Cullen BR (2004) Human microRNAs are processed from capped, polyadenylated transcripts that can also function as mRNAs. RNA 10:1957-1966. doi:10.1261/ rna.7135204

10. Lee Y, Kim M, Han J et al (2004) MicroRNA genes are transcribed by RNA polymerase II. EMBO J 23:4051-4060. doi:10. 1038/sj.emboj.7600385

11. Borchert GM, Lanier W, Davidson BL (2006) RNA polymerase III transcribes human microRNAs. Nat Struct Mol Biol 13:1097-1101. doi:10.1038/nsmb1167

12. Lee Y, Ahn C, Han J et al (2003) The nuclear RNase III Drosha initiates microRNA processing. Nature 425:415-419. doi:10.1038/nature01957

13. Gregory RI, Yan K-P, Amuthan G et al (2004) The microprocessor complex mediates the genesis of microRNAs. Nature 432:235-240. doi:10.1038/nature03120

14. Denli AM, Tops BBJ, Plasterk RHA et al (2004) Processing of primary microRNAs by the microprocessor complex. Nature 432:231-235. doi:10.1038/nature03049

15. Han J, Lee Y, Yeom K-H et al (2004) The Drosha-DGCR8 complex in primary microRNA processing. Gen Dev 18:3016-3027. doi:10.1101/gad.1262504

16. Morlando M, Ballarino M, Gromak N et al (2008) Primary microRNA transcripts are processed co-transcriptionally. Nat Struct Mol Biol 15:902-909. doi:10.1038/nsmb.1475

17. Kim Y-K, Kim VN (2007) Processing of intronic microRNAs. EMBO J 26:775-783. doi:10.1038/sj.emboj.7601512

18. Yi R, Qin Y, Macara IG, Cullen BR (2003) Exportin-5 mediates the nuclear export of pre-microRNAs and short hairpin RNAs. Genes Dev 17:3011-3016. doi:10.1101/gad.1158803

19. Lund E, Güttinger S, Calado A et al (2004) Nuclear export of microRNA precursors. Science 303:95-98. doi:10.1126/ science. 1090599

20. Chendrimada TP, Gregory RI, Kumaraswamy E et al (2005) TRBP recruits the Dicer complex to Ago2 for microRNA processing and gene silencing. Nature 436:740-744. doi:10.1038/ nature 03868

21. Haase AD, Jaskiewicz L, Zhang $H$ et al (2005) TRBP, a regulator of cellular PKR and HIV-1 virus expression, interacts with Dicer and functions in RNA silencing. EMBO Rep 6:961-967. doi:10.1038/sj.embor.7400509

22. Lee Y, Hur I, Park S-Y et al (2006) The role of PACT in the RNA silencing pathway. EMBO J 25:522-532. doi:10.1038/sj.e mboj.7600942

23. Kok KH, Ng M-HJ, Ching Y-P, Jin D-Y (2007) Human TRBP and PACT directly interact with each other and associate with dicer to facilitate the production of small interfering RNA. J Biol Chem 282:17649-17657. doi:10.1074/jbc.M611768200

24. Koscianska E, Starega-Roslan J, Krzyzosiak WJ (2011) The role of Dicer protein partners in the processing of microRNA precursors. PLoS One 6:e28548. doi:10.1371/ journal.pone.0028548

25. Bernstein E, Caudy AA, Hammond SM, Hannon GJ (2001) Role for a bidentate ribonuclease in the initiation step of RNA interference. Nature 409:363-366. doi:10.1038/35053110

26. Hutvágner G, McLachlan J, Pasquinelli AE et al (2001) A cellular function for the RNA-interference enzyme Dicer in the maturation of the let-7 small temporal RNA. Science 293:834-838. doi:10.1126/science. 1062961

27. MacRae IJ, Zhou K, Doudna JA (2007) Structural determinants of RNA recognition and cleavage by Dicer. Nat Struct Mol Biol 14:934-940. doi:10.1038/nsmb1293

28. Starega-Roslan J, Koscianska E, Kozlowski P, Krzyzosiak WJ (2011) The role of the precursor structure in the biogenesis of microRNA. Cell Mol Life Sci 68:2859-2871. doi:10.1007/ s00018-011-0726-2
29. Berezikov E, Chung W-J, Willis J et al (2007) Mammalian mirtron genes. Mol Cell 28:328-336. doi:10.1016/j.molcel.2007.09.028

30. Ruby JG, Jan CH, Bartel DP (2007) Intronic microRNA precursors that bypass Drosha processing. Nature 448:83-86. doi:10.1038/nature05983

31. Cheloufi S, Dos Santos CO, Chong MMW, Hannon GJ (2010) A dicer-independent miRNA biogenesis pathway that requires Ago catalysis. Nature 465:584-589. doi:10.1038/nature09092

32. Cifuentes D, Xue H, Taylor DW et al (2010) A novel miRNA processing pathway independent of Dicer requires Argonaute2 catalytic activity. Science 328:1694-1698. doi:10.1126/ science.1190809

33. Yang J-S, Maurin T, Robine N et al (2010) Conserved vertebrate mir-451 provides a platform for Dicer-independent, Ago2mediated microRNA biogenesis. Proc Natl Acad Sci USA 107:15163-15168. doi:10.1073/pnas.1006432107

34. Morin RD, O'Connor MD, Griffith M et al (2008) Application of massively parallel sequencing to microRNA profiling and discovery in human embryonic stem cells. Genom Res 18:610 621. doi:10.1101/gr.7179508

35. Azuma-Mukai A, Oguri H, Mituyama T et al (2008) Characterization of endogenous human Argonautes and their miRNA partners in RNA silencing. Proc Natl Acad Sci USA 105:79647969. doi:10.1073/pnas.0800334105

36. Wu H, Ye C, Ramirez D, Manjunath N (2009) Alternative processing of primary microRNA transcripts by Drosha generates $5^{\prime}$ end variation of mature microRNA. PLoS One 4:e7566. doi:10.1371/journal.pone.0007566

37. Neilsen CT, Goodall GJ, Bracken CP (2012) IsomiRs-the overlooked repertoire in the dynamic microRNAome. Tren Genet 28:544-549. doi:10.1016/j.tig.2012.07.005

38. Chan Y-T, Lin Y-C, Lin R-J et al (2013) Concordant and discordant regulation of target genes by miR-31 and its isoforms. PLoS One 8:e58169. doi:10.1371/journal.pone.0058169

39. Kozlowska E, Krzyzosiak WJ, Koscianska E (2013) Regulation of Huntingtin gene expression by miRNA-137, -214, -148a, and their respective isomiRs. Int J Mol Sci 14:16999-17016. doi:10. 3390/ijms140816999

40. Landgraf P, Rusu M, Sheridan $R$ et al (2007) A mammalian microRNA expression atlas based on small RNA library sequencing. Cell 129:1401-1414. doi:10.1016/j.cell.2007.04.040

41. Katoh T, Sakaguchi Y, Miyauchi K et al (2009) Selective stabilization of mammalian microRNAs by $3^{\prime}$ adenylation mediated by the cytoplasmic poly(A) polymerase GLD-2. Gen Dev 23:433-438. doi:10.1101/gad.1761509

42. Burroughs aM, Ando Y, De Hoon MJL et al (2010) A comprehensive survey of $3^{\prime}$ animal miRNA modification events and a possible role for $3^{\prime}$ adenylation in modulating miRNA targeting effectiveness. Genom Res 20:1398-1410. doi:10.1101 /gr.106054.110

43. Heo I, Joo C, Cho J et al (2008) Lin28 mediates the terminal uridylation of let-7 precursor MicroRNA. Mol Cell 32:276284. doi:10.1016/j.molcel.2008.09.014

44. Chen Y, Sinha K, Perumal K, Reddy R (2000) Effect of $3^{\prime}$ terminal adenylic acid residue on the uridylation of human small RNAs in vitro and in frog oocytes. RNA 6:1277-1288

45. Kim Y-K, Heo I, Kim VN (2010) Modifications of small RNAs and their associated proteins. Cell 143:703-709. doi:10.1016/j. cell.2010.11.018

46. Kai ZS, Pasquinelli AE (2010) MicroRNA assassins: factors that regulate the disappearance of miRNAs. Nat Struct Mol Biol 17:5-10. doi:10.1038/nsmb.1762

47. Shen B, Goodman HM (2004) Uridine addition after microRNA-directed cleavage. Science 306:997. doi:10.1126/science. 1103521 
48. Mullen TE, Marzluff WF (2008) Degradation of histone mRNA requires oligouridylation followed by decapping and simultaneous degradation of the mRNA both $5^{\prime}$ to $3^{\prime}$ and $3^{\prime}$ to $5^{\prime}$. Gen Dev 22:50-65. doi:10.1101/gad.1622708

49. Heo I, Joo C, Kim Y-K et al (2009) TUT4 in concert with Lin28 suppresses microRNA biogenesis through pre-microRNA uridylation. Cell 138:696-708. doi:10.1016/j.cell.2009.08.002

50. Scott DD, Norbury CJ (2013) RNA decay via $3^{\prime}$ uridylation. Biochim Biophys Acta 1829:654-665. doi:10.1016/j.bbagrm.2013.01.009

51. Luciano DJ, Mirsky H, Vendetti NJ, Maas S (2004) RNA editing of a miRNA precursor. RNA 10:1174-1177. doi:10.1261/ rna.7350304

52. Yang W, Chendrimada TP, Wang Q et al (2006) Modulation of microRNA processing and expression through RNA editing by ADAR deaminases. Nat Struct Mol Biol 13:13-21. doi:10.1038/nsmb1041

53. Blow MJ, Grocock RJ, van Dongen $S$ et al (2006) RNA editing of human microRNAs. Genom Biol 7:R27. doi:10.1186/gb-2006-7-4-r27

54. Kawahara Y, Zinshteyn B, Chendrimada TP et al (2007) RNA editing of the microRNA-151 precursor blocks cleavage by the Dicer-TRBP complex. EMBO Rep 8:763-769. doi:10.1038/sj.e mbor.7401011

55. Kawahara Y, Megraw M, Kreider E et al (2008) Frequency and fate of microRNA editing in human brain. Nucl Acids Res 36:5270-5280. doi:10.1093/nar/gkn479

56. Iizasa H, Wulff B-E, Alla NR et al (2010) Editing of EpsteinBarr virus-encoded BART6 microRNAs controls their dicer targeting and consequently affects viral latency. J Biol Chem 285:33358-33370. doi:10.1074/jbc.M110.138362

57. Kawahara Y, Zinshteyn B, Sethupathy P et al (2007) Redirection of silencing targets by adenosine-to-inosine editing of miRNAs. Science 315:1137-1140. doi:10.1126/science. 1138050

58. Gommans WM (2012) A-to-I editing of microRNAs: regulating the regulators? Semin Cell Dev Biol 23:251-257. doi:10.1016/j.semcdb.2011.09.018

59. Höck J, Meister G (2008) The argonaute protein family. Genom Biol 9:210. doi:10.1186/gb-2008-9-2-210

60. Meister G (2013) Argonaute proteins: functional insights and emerging roles. Nat Rev Genet. doi:10.1038/nrg3462

61. Song J-J, Smith SK, Hannon GJ, Joshua-Tor L (2004) Crystal structure of Argonaute and its implications for RISC slicer activity. Science 305:1434-1437. doi:10.1126/science.1102514

62. Cerutti L, Mian N, Bateman A (2000) Domains in gene silencing and cell differentiation proteins: the novel PAZ domain and redefinition of the Piwi domain. Tren Biochem Sci 25:481-482

63. Song J-J, Liu J, Tolia NH et al (2003) The crystal structure of the Argonaute2 PAZ domain reveals an RNA binding motif in RNAi effector complexes. Nat Struct Biol 10:1026-1032. doi:10.1038/nsb1016

64. Lingel A, Simon B, Izaurralde E, Sattler M (2004) Nucleic acid $3^{\prime}$-end recognition by the Argonaute2 PAZ domain. Nat Struct Mol Biol 11:576-577. doi:10.1038/nsmb777

65. Ma J-B, Ye K, Patel DJ (2004) Structural basis for overhangspecific small interfering RNA recognition by the PAZ domain. Nature 429:318-322. doi:10.1038/nature02519

66. Schirle NT, MacRae IJ (2012) The crystal structure of human Argonaute2. Science 336:1037-1040. doi:10.1126/ science. 1221551

67. Elkayam E, Kuhn C-D, Tocilj A et al (2012) The structure of human argonaute-2 in complex with miR-20a. Cell 150:100110. doi:10.1016/j.cell.2012.05.017

68. Liu J, Carmell MA, Rivas FV et al (2004) Argonaute2 is the catalytic engine of mammalian RNAi. Science 80(305):14371441. doi:10.1126/science. 1102513
69. Meister G, Landthaler M, Patkaniowska A et al (2004) Human Argonaute2 mediates RNA cleavage targeted by miRNAs and siRNAs. Mol Cell 15:185-197. doi:10.1016/j.molcel.2004.07.007

70. Rivas FV, Tolia NH, Song J-J et al (2005) Purified Argonaute2 and an siRNA form recombinant human RISC. Nat Struct Mol Biol 12:340-349. doi:10.1038/nsmb918

71. Hauptmann J, Dueck A, Harlander S et al (2013) Turning catalytically inactive human Argonaute proteins into active slicer enzymes. Nat Struct Mol Biol 20:814-817. doi:10.1038/nsmb.2577

72. Schwarz DS, Tomari Y, Zamore PD (2004) The RNA-induced silencing complex is a $\mathrm{Mg} 2+$-dependent endonuclease. Curr Biol 14:787-791. doi:10.1016/j.cub.2004.03.008

73. Martinez J, Tuschl T (2004) RISC is a $5^{\prime}$ phosphomonoesterproducing RNA endonuclease. Gen Dev 18:975-980. doi:10.1101/gad.1187904

74. Nowotny M, Gaidamakov SA, Crouch RJ, Yang W (2005) Crystal structures of RNase $\mathrm{H}$ bound to an RNA/DNA hybrid: substrate specificity and metal-dependent catalysis. Cell 121:10051016. doi:10.1016/j.cell.2005.04.024

75. Tomari Y, Du T, Zamore PD (2007) Sorting of Drosophila small silencing RNAs. Cell 130:299-308. doi:10.1016/j. cell.2007.05.057

76. Okamura K, Liu N, Lai EC (2009) Distinct mechanisms for microRNA strand selection by Drosophila Argonautes. Mol Cell 36:431-444. doi:10.1016/j.molcel.2009.09.027

77. Czech B, Zhou R, Erlich Y et al (2009) Hierarchical rules for Argonaute loading in Drosophila. Mol Cell 36:445-456. doi:10.1016/j.molcel.2009.09.028

78. Ghildiyal M, Xu J, Seitz H et al (2010) Sorting of Drosophila small silencing RNAs partitions microRNA* strands into the RNA interference pathway. RNA 16:43-56. doi:10.1261/ rna. 1972910

79. Czech B, Hannon GJ (2011) Small RNA sorting: matchmaking for Argonautes. Nat Rev Genet 12:19-31. doi:10.1038/nrg2916

80. Dueck A, Ziegler C, Eichner A et al (2012) microRNAs associated with the different human Argonaute proteins. Nucl Acids Res 40:9850-9862. doi:10.1093/nar/gks705

81. Wang D, Zhang Z, O'Loughlin E et al (2012) Quantitative functions of Argonaute proteins in mammalian development. Gen Dev 26:693-704. doi:10.1101/gad.182758.111

82. Kawamata T, Tomari Y (2010) Making RISC. Tren Biochem Sci 35:368-376. doi:10.1016/j.tibs.2010.03.009

83. Nykänen A, Haley B, Zamore PD (2001) ATP requirements and small interfering RNA structure in the RNA interference pathway. Cell 107:309-321

84. Kawamata T, Seitz H, Tomari Y (2009) Structural determinants of miRNAs for RISC loading and slicer-independent unwinding. Nat Struct Mol Biol 16:953-960. doi:10.1038/nsmb.1630

85. Yoda M, Kawamata T, Paroo Z et al (2010) ATP-dependent human RISC assembly pathways. Nat Struct Mol Biol 17:1723. doi: $10.1038 / \mathrm{nsmb} .1733$

86. Liu X, Jin D-Y, McManus MT, Mourelatos Z (2012) Precursor microRNA-programmed silencing complex assembly pathways in mammals. Mol Cell 46:507-517. doi:10.1016/j.molcel.2012.03.010

87. Maniataki E, Mourelatos Z (2005) A human, ATP-independent, RISC assembly machine fueled by pre-miRNA. Gen Dev 19:2979-2990. doi:10.1101/gad.1384005

88. MacRae IJ, Ma E, Zhou M et al (2008) In vitro reconstitution of the human RISC-loading complex. Proc Natl Acad Sci USA 105:512-517. doi:10.1073/pnas.0710869105

89. Gredell JA, Dittmer MJ, Wu M et al (2010) Recognition of siRNA asymmetry by TAR RNA binding protein. Biochemistry 49:3148-3155. doi:10.1021/bi902189s 
90. Noland CL, Ma E, Doudna JA (2011) siRNA repositioning for guide strand selection by human Dicer complexes. Mol Cell 43:110-121. doi:10.1016/j.molcel.2011.05.028

91. Noland CL, Doudna JA (2013) Multiple sensors ensure guide strand selection in human RNAi pathways. RNA 19:639-648. doi:10.1261/rna.037424.112

92. Kanellopoulou C, Muljo SA, Kung AL et al (2005) Dicerdeficient mouse embryonic stem cells are defective in differentiation and centromeric silencing. Gen Dev 19:489-501. doi:10.1101/gad.1248505

93. Murchison EP, Partridge JF, Tam OH et al (2005) Characterization of Dicer-deficient murine embryonic stem cells. Proc Natl Acad Sci USA 102:12135-12140. doi:10.1073/p nas.0505479102

94. Betancur JG, Tomari Y (2012) Dicer is dispensable for asymmetric RISC loading in mammals. RNA 18:24-30. doi:10.1261/ rna.029785.111

95. Ro S, Park C, Young D et al (2007) Tissue-dependent paired expression of miRNAs. Nucl Acids Res 35:5944-5953. doi:10.1 093/nar/gkm641

96. Chiang HR, Schoenfeld LW, Ruby JG et al (2010) Mammalian microRNAs: experimental evaluation of novel and previously annotated genes. Gen Dev 24:992-1009. doi:10.1101/ gad. 1884710

97. Griffiths-Jones S, Hui JHL, Marco A, Ronshaugen M (2011) MicroRNA evolution by arm switching. EMBO Rep 12:172177. doi:10.1038/embor.2010.191

98. Yang X, Du WW, Li H et al (2013) Both mature miR-17-5p and passenger strand miR-17-3p target TIMP3 and induce prostate tumor growth and invasion. Nucl Acids Res 41:9688-9704. doi: 10.1093/nar/gkt680

99. Winter J, Diederichs S (2013) Argonaute-3 activates the let-7a passenger strand microRNA. RNA Biol 8:1149-1157

100. Khvorova A, Reynolds A, Jayasena SD (2003) Functional siRNAs and miRNAs exhibit strand bias. Cell 115:209-216. doi:10.1016/S0092-8674(03)00801-8

101. Schwarz DS, Hutvágner G, Du T et al (2003) Asymmetry in the assembly of the RNAi enzyme complex. Cell 115:199-208

102. Krol J, Sobczak K, Wilczynska U et al (2004) Structural features of microRNA (miRNA) precursors and their relevance to miRNA biogenesis and small interfering RNA/short hairpin RNA design. J Biol Chem 279:42230-42239. doi:10.1074/jbc. M404931200

103. Frank F, Sonenberg N, Nagar B (2010) Structural basis for 5 -nucleotide base-specific recognition of guide RNA by human AGO2. Nature 465:818-822. doi:10.1038/nature09039

104. Hu HY, Yan Z, Xu Y et al (2009) Sequence features associated with microRNA strand selection in humans and flies. BMC Genom 10:413. doi:10.1186/1471-2164-10-413

105. Lee HY, Doudna JA (2012) TRBP alters human precursor microRNA processing in vitro. RNA 18:2012-2019. doi:10.1261/rna.035501.112

106. Kwak PB, Tomari Y (2012) The N domain of Argonaute drives duplex unwinding during RISC assembly. Nat Struct Mol Biol 19:145-151. doi:10.1038/nsmb.2232

107. Gu S, Jin L, Huang Y et al (2012) Slicing-independent RISC activation requires the argonaute PAZ domain. Curr Biol 22:1536-1542. doi:10.1016/j.cub.2012.06.040

108. Diederichs S, Haber DA (2007) Dual role for argonautes in microRNA processing and posttranscriptional regulation of microRNA expression. Cell 131:1097-1108. doi:10.1016/j. cell.2007.10.032

109. O'Carroll D, Mecklenbrauker I, Das PP et al (2007) A slicerindependent role for Argonaute 2 in hematopoiesis and the microRNA pathway. Gen Dev 21:1999-2004. doi:10.1101/ gad. 1565607
110. Winter J, Diederichs S (2011) Argonaute proteins regulate microRNA stability: increased microRNA abundance by Argonaute proteins is due to microRNA stabilization. RNA Biol 8:1149-1157. doi:10.4161/rna.8.6.17665

111. Smibert P, Yang J-S, Azzam G et al (2013) Homeostatic control of Argonaute stability by microRNA availability. Nat Struct Mol Biol 20:789-795. doi:10.1038/nsmb.2606

112. Janas MM, Wang B, Harris AS et al (2012) Alternative RISC assembly: binding and repression of microRNA-mRNA duplexes by human Ago proteins. RNA 18:2041-2055. doi:10.1261/rna.035675.112

113. Stalder L, Heusermann W, Sokol L et al (2013) The rough endoplasmatic reticulum is a central nucleation site of siRNAmediated RNA silencing. EMBO J 32:1115-1127. doi:10.1038/ emboj.2013.52

114. Flores O, Nakayama S, Whisnant AW et al (2013) Mutational inactivation of herpes simplex virus 1 microRNAs identifies viral mRNA targets and reveals phenotypic effects in culture. $\mathbf{J}$ Virol 87:6589-6603. doi:10.1128/JVI.00504-13

115. Song E, Lee S-K, Dykxhoorn DM et al (2003) Sustained small interfering RNA-mediated human immunodeficiency virus type 1 inhibition in primary macrophages. J Virol 77:7174-7181

116. Chatterjee S, Grosshans H (2009) Active turnover modulates mature microRNA activity in Caenorhabditis elegans. Nature 461:546-549. doi:10.1038/nature08349

117. Wang B, Love TM, Call ME et al (2006) Recapitulation of short RNA-directed translational gene silencing in vitro. Mol Cell 22:553-560. doi:10.1016/j.molcel.2006.03.034

118. Wang B, Li S, Qi HH et al (2009) Distinct passenger strand and mRNA cleavage activities of human Argonaute proteins. Nat Struct Mol Biol 16:1259-1266. doi:10.1038/nsmb.1712

119. Ricci EP, Limousin T, Soto-Rifo R et al (2011) Activation of a microRNA response in trans reveals a new role for poly(A) in translational repression. Nucl Acids Res 39:5215-5231. doi:10 $.1093 / \mathrm{nar} / \mathrm{gkr} 086$

120. Ameres SL, Martinez J, Schroeder R (2007) Molecular basis for target RNA recognition and cleavage by human RISC. Cell 130:101-112. doi:10.1016/j.cell.2007.04.037

121. Rana TM (2007) Illuminating the silence: understanding the structure and function of small RNAs. Nat Rev Mol Cell Biol 8:23-36. doi:10.1038/nrm2085

122. Luo KQ, Chang DC (2004) The gene-silencing efficiency of siRNA is strongly dependent on the local structure of mRNA at the targeted region. Biochem Biophys Res Commun 318:303310. doi:10.1016/j.bbrc.2004.04.027

123. Overhoff M, Alken M, Far RK-K et al (2005) Local RNA target structure influences siRNA efficacy: a systematic global analysis. J Mol Biol 348:871-881. doi:10.1016/j.jmb.2005.03.012

124. Schubert S, Grünweller A, Erdmann VA, Kurreck J (2005) Local RNA target structure influences siRNA efficacy: systematic analysis of intentionally designed binding regions. $\mathrm{J}$ Mol Biol 348:883-893. doi:10.1016/j.jmb.2005.03.011

125. Heale BSE, Soifer HS, Bowers C, Rossi JJ (2005) siRNA target site secondary structure predictions using local stable substructures. Nucl Acids Res 33:e30. doi:10.1093/nar/gni026

126. Long D, Lee R, Williams P et al (2007) Potent effect of target structure on microRNA function. Nat Struct Mol Biol 14:287294. doi: $10.1038 / \mathrm{nsmb} 1226$

127. Lim LP, Lau NC, Weinstein EG et al (2003) The microRNAs of Caenorhabditis elegans. Gen Dev 17:991-1008. doi:10.1101/ gad. 1074403

128. Doench JG, Sharp PA (2004) Specificity of microRNA target selection in translational repression. Gen Dev 18:504-511. doi:10.1101/gad.1184404

129. Bartel DP (2009) MicroRNAs: target recognition and regulatory functions. Cell 136:215-233. doi:10.1016/j.cell.2009.01.002 
130. Witkos TM, Koscianska E, Krzyzosiak WJ (2011) Practical aspects of microRNA target prediction. Curr Mol Med 11:93-109

131. Helwak A, Kudla G, Dudnakova T, Tollervey D (2013) Mapping the human miRNA interactome by CLASH reveals frequent noncanonical binding. Cell 153:654-665. doi:10.1016/j. cell.2013.03.043

132. Shin C, Nam J-W, Farh KK-H et al (2010) Expanding the microRNA targeting code: functional sites with centered pairing. Mol Cell 38:789-802. doi:10.1016/j.molcel.2010.06.005

133. Chi SW, Hannon GJ, Darnell RB (2012) An alternative mode of microRNA target recognition. Nat Struct Mol Biol 19:321-327. doi: $10.1038 / \mathrm{nsmb} .2230$

134. Lal A, Navarro F, Maher CA et al (2009) miR-24 Inhibits cell proliferation by targeting E2F2, MYC, and other cell-cycle genes via binding to "seedless" $3^{\prime}$ UTR microRNA recognition elements. Mol Cell 35:610-625. doi:10.1016/j.molcel.2009.08.020

135. Duursma AM, Kedde M, Schrier M et al (2008) miR-148 targets human DNMT3b protein coding region. RNA 14:872-877. doi:10.1261/rna.972008

136. Forman JJ, Legesse-Miller A, Coller Ha (2008) A search for conserved sequences in coding regions reveals that the let-7 microRNA targets Dicer within its coding sequence. Proc Natl Acad Sci USA 105:14879-14884. doi:10.1073/p nas.0803230105

137. Lal A, Kim HH, Abdelmohsen K et al (2008) p16(INK4a) translation suppressed by miR-24. PLoS One 3:e1864. doi:10.1371/ journal.pone.0001864

138. Tay Y, Zhang J, Thomson AM et al (2008) MicroRNAs to Nanog, Oct4 and Sox 2 coding regions modulate embryonic stem cell differentiation. Nature 455:1124-1128. doi:10.1038/ nature 07299

139. Elcheva I, Goswami S, Noubissi FK, Spiegelman VS (2009) CRD-BP protects the coding region of betaTrCP1 mRNA from miR-183-mediated degradation. Mol Cell 35:240-246. doi:10.1016/j.molcel.2009.06.007

140. Jopling CL, Yi M, Lancaster AM et al (2005) Modulation of hepatitis C virus RNA abundance by a liver-specific MicroRNA. Science 309:1577-1581. doi:10.1126/science.1113329

141. Ørom UA, Nielsen FC, Lund AH (2008) MicroRNA-10a binds the 5'UTR of ribosomal protein mRNAs and enhances their translation. Mol Cell 30:460-471. doi:10.1016/j.molcel.2008.05.001

142. Tsai N-P, Lin Y-L, Wei L-N (2009) MicroRNA mir-346 targets the $5^{\prime}$-untranslated region of receptor-interacting protein 140 (RIP140) mRNA and up-regulates its protein expression. Biochem J 424:411-418. doi:10.1042/BJ20090915

143. Chi SW, Zang JB, Mele A, Darnell RB (2009) Argonaute HITSCLIP decodes microRNA-mRNA interaction maps. Nature 460:479-486

144. Hafner M, Landthaler M, Burger L et al (2010) Transcriptomewide identification of RNA-binding protein and microRNA target sites by PAR-CLIP. Cell 141:129-141. doi:10.1016/j. cell.2010.03.009

145. Leung AKL, Young AG, Bhutkar A et al (2011) Genome-wide identification of Ago2 binding sites from mouse embryonic stem cells with and without mature microRNAs. Nat Struct Mol Biol 18:237-244. doi:10.1038/nsmb.1991

146. Gu S, Jin L, Zhang F et al (2009) Biological basis for restriction of microRNA targets to the $3^{\prime}$ untranslated region in mammalian mRNAs. Nat Struct Mol Biol 16:144-150. doi:10.1038/nsmb. 1552

147. Broderick Ja, Salomon WE, Ryder SP et al (2011) Argonaute protein identity and pairing geometry determine cooperativity in mammalian RNA silencing. RNA 17:1858-1869. doi:10.1261/ rna.2778911

148. Moretti F, Thermann R, Hentze MW (2010) Mechanism of translational regulation by miR-2 from sites in the $5^{\prime}$ untranslated region or the open reading frame. RNA 16:24932502. doi: $10.1261 /$ rna. 2384610

149. Grimson A, Farh KK-H, Johnston WK et al (2007) MicroRNA targeting specificity in mammals: determinants beyond seed pairing. Mol Cell 27:91-105. doi:10.1016/j.molcel.2007.06.017

150. Saetrom P, Heale BSE, Snøve O et al (2007) Distance constraints between microRNA target sites dictate efficacy and cooperativity. Nucl Acids Res 35:2333-2342. doi:10.1093/nar/gkm133

151. Rinck A, Preusse M, Laggerbauer B et al (2013) The human transcriptome is enriched for miRNA-binding sites located in cooperativity-permitting distance. RNA Biol 10:1125-1135. doi:10.4161/rna.24955

152. Thomas M, Lieberman J, Lal A (2010) Desperately seeking microRNA targets. Nat Struct Mol Biol 17:1169-1174. doi:10.1038/nsmb.1921

153. Pasquinelli AE (2012) MicroRNAs and their targets: recognition, regulation and an emerging reciprocal relationship. Nat Rev Genet 13:271-282. doi:10.1038/nrg3162

154. John B, Enright AJ, Aravin A et al (2004) Human MicroRNA targets. PLoS Biol 2:e363. doi:10.1371/journal.pbio.0020363

155. Rehmsmeier M, Steffen P, Hochsmann M, Giegerich R (2004) Fast and effective prediction of microRNA/target duplexes. RNA 10:1507-1517. doi:10.1261/rna.5248604

156. Krüger J, Rehmsmeier M (2006) RNAhybrid: microRNA target prediction easy, fast and flexible. Nucl Acids Res 34:W451-W454. doi:10.1093/nar/gk1243

157. Krek A, Grün D, Poy MN et al (2005) Combinatorial microRNA target predictions. Nat Genet 37:495-500. doi:10.1038/ ng 1536

158. Lewis BP, Burge CB, Bartel DP (2005) Conserved seed pairing, often flanked by adenosines, indicates that thousands of human genes are microRNA targets. Cell 120:15-20. doi:10.1016/j. cell.2004.12.035

159. Kertesz M, Iovino N, Unnerstall U et al (2007) The role of site accessibility in microRNA target recognition. Nat Genet 39:1278-1284

160. Min H, Yoon S (2010) Got target? Computational methods for microRNA target prediction and their extension. Exp Mol Med 42:233-244. doi:10.3858/emm.2010.42.4.032

161. Incarnato D, Neri F, Diamanti D, Oliviero S (2013) MREdictor: a two-step dynamic interaction model that accounts for mRNA accessibility and Pumilio binding accurately predicts microRNA targets. Nucl Acids Res 41:8421-8433. doi:10.1093/nar/ gkt629

162. Thomson DW, Bracken CP, Goodall GJ (2011) Experimental strategies for microRNA target identification. Nucl Acids Res 39:6845-6853. doi:10.1093/nar/gkr330

163. Vasudevan S (2012) Functional validation of microRNA-target RNA interactions. Methods 58:126-134. doi:10.1016/j.ymeth. 2012.08.002

164. Burroughs AM, Ando Y, de Hoon ML et al (2011) Deepsequencing of human Argonaute-associated small RNAs provides insight into miRNA sorting and reveals Argonaute association with RNA fragments of diverse origin. RNA Biol 8:158-177. doi:10.4161/rna.8.1.14300

165. Ule J, Jensen KB, Ruggiu $M$ et al (2003) CLIP identifies Novaregulated RNA networks in the brain. Science 302:1212-1215. doi:10.1126/science. 1090095

166. Ule J, Jensen K, Mele A, Darnell RB (2005) CLIP: a method for identifying protein-RNA interaction sites in living cells. Methods 37:376-386. doi:10.1016/j.ymeth.2005.07.018

167. König J, Zarnack K, Luscombe NM, Ule J (2011) Protein-RNA interactions: new genomic technologies and perspectives. Nat Rev Genet 13:77-83. doi:10.1038/nrg3141

168. Kudla G, Granneman S, Hahn D et al (2011) Cross-linking, ligation, and sequencing of hybrids reveals RNA-RNA 
interactions in yeast. Proc Natl Acad Sci USA 108:1001010015. doi:10.1073/pnas.1017386108

169. Di Giammartino DC, Nishida K, Manley JL (2011) Mechanisms and consequences of alternative polyadenylation. Mol Cell 43:853-866. doi:10.1016/j.molcel.2011.08.017

170. Elkon R, Ugalde AP, Agami R (2013) Alternative cleavage and polyadenylation: extent, regulation and function. Nat Rev Genet 14:496-506. doi:10.1038/nrg3482

171. Boutet SC, Cheung TH, Quach NL et al (2012) Alternative polyadenylation mediates microRNA regulation of muscle stem cell function. Cell Stem Cell 10:327-336. doi:10.1016/j. stem.2012.01.017

172. Kedde M, Strasser MJ, Boldajipour B et al (2007) RNA-binding protein Dnd1 inhibits microRNA access to target mRNA. Cell 131:1273-1286. doi:10.1016/j.cell.2007.11.034

173. Kedde M, van Kouwenhove M, Zwart W et al (2010) A Pumilio-induced RNA structure switch in p27-3' UTR controls miR-221 and miR-222 accessibility. Nat Cell Biol 12:10141020. doi: $10.1038 / \mathrm{ncb} 2105$

174. Borchert GM, Gilmore BL, Spengler RM et al (2009) Adenosine deamination in human transcripts generates novel microRNA binding sites. Hum Mol Genet 18:4801-4807. doi:10.109 3/hmg/ddp443

175. Liang H, Landweber LF (2007) Hypothesis: RNA editing of microRNA target sites in humans? RNA 13:463-467. doi:10.1261/rna.296407

176. Sumazin P, Yang X, Chiu H-S et al (2011) An extensive microRNA-mediated network of RNA-RNA interactions regulates established oncogenic pathways in glioblastoma. Cell 147:370 381. doi:10.1016/j.cell.2011.09.041

177. Tay Y, Kats L, Salmena L et al (2011) Coding-independent regulation of the tumor suppressor PTEN by competing endogenous mRNAs. Cell 147:344-357. doi:10.1016/j.cell.2011.09.029

178. Salmena L, Poliseno L, Tay Y et al (2011) A ceRNA hypothesis: the Rosetta stone of a hidden RNA language? Cell 146:353358. doi:10.1016/j.cell.2011.07.014

179. Ebert MS, Neilson JR, Sharp PA (2007) MicroRNA sponges: competitive inhibitors of small RNAs in mammalian cells. Nat Meth 4:721-726. doi:10.1038/nmeth1079

180. Gentner B, Schira G, Giustacchini A et al (2009) Stable knockdown of microRNA in vivo by lentiviral vectors. Nat Meth 6:63-66. doi:10.1038/nmeth.1277

181. Ebert MS, Sharp PA (2010) MicroRNA sponges: progress and possibilities. RNA 16:2043-2050. doi:10.1261/rna.2414110

182. Cesana M, Cacchiarelli D, Legnini I et al (2011) A long noncoding RNA controls muscle differentiation by functioning as a competing endogenous RNA. Cell 147:358-369. doi:10.1016/j. cell.2011.09.028

183. Hansen TB, Jensen TI, Clausen BH et al (2013) Natural RNA circles function as efficient microRNA sponges. Nature 495:384-388. doi:10.1038/nature11993

184. Memczak S, Jens M, Elefsinioti A et al (2013) Circular RNAs are a large class of animal RNAs with regulatory potency. Nature 495:333-338. doi:10.1038/nature11928

185. Poliseno L, Salmena L, Zhang J et al (2010) A coding-independent function of gene and pseudogene mRNAs regulates tumour biology. Nature 465:1033-1038. doi:10.1038/nature09144

186. Cazalla D, Yario T, Steitz JA, Steitz J (2010) Down-regulation of a host microRNA by a Herpesvirus saimiri noncoding RNA. Science 328:1563-1566. doi:10.1126/science.1187197

187. Wu L, Fan J, Belasco JG (2006) MicroRNAs direct rapid deadenylation of mRNA. PNAS 103:4034-4039. doi:10.1073/p nas.0510928103

188. Eulalio A, Huntzinger E, Nishihara T et al (2009) Deadenylation is a widespread effect of miRNA regulation. RNA 15:2132. doi:10.1261/rna.1399509
189. Guo H, Ingolia NT, Weissman JS, Bartel DP (2010) Mammalian microRNAs predominantly act to decrease target mRNA levels. Nature 466:835-840. doi:10.1038/nature09267.Mammalian

190. Wightman B, Ha I, Ruvkun G (1993) Posttranscriptional regulation of the heterochronic gene lin-14 by lin- 4 mediates temporal pattern formation in Caenorhabditis elegans. Cell 75:855-862

191. Olsen PH, Ambros V (1999) The lin-4 regulatory RNA controls developmental timing in Caenorhabditis elegans by blocking LIN-14 protein synthesis after the initiation of translation. Dev Biol 216:671-680. doi:10.1006/dbio 1999.9523

192. Humphreys DT, Westman BJ, Martin DIK, Preiss T (2005) MicroRNAs control translation initiation by inhibiting eukaryotic initiation factor 4E/cap and poly(A) tail function. Proc Natl Acad Sci USA 102:16961-16966. doi:10.1073/p nas.0506482102

193. Eulalio A, Tritschler F, Izaurralde E (2009) The GW182 protein family in animal cells: new insights into domains required for miRNA-mediated gene silencing. RNA 15:1433-1442. doi:10.1261/rna.1703809

194. Eystathioy T, Chan EKL, Tenenbaum SA et al (2002) A phosphorylated cytoplasmic autoantigen, GW182, associates with a unique population of human mRNAs within novel cytoplasmic speckles. Mol Biol Cell 13:1338-1351. doi:10.1091/ mbc.01-11-0544

195. Till S, Lejeune E, Thermann R et al (2007) A conserved motif in Argonaute-interacting proteins mediates functional interactions through the Argonaute PIWI domain. Nat Struct Mol Biol 14:897-903. doi:10.1038/nsmb1302

196. Takimoto K, Wakiyama M, Yokoyama S (2009) Mammalian GW182 contains multiple Argonaute-binding sites and functions in microRNA-mediated translational repression. RNA 15:1078-1089. doi:10.1261/rna.1363109

197. Eulalio A, Helms S, Fritzsch C et al (2009) A C-terminal silencing domain in GW182 is essential for miRNA function. RNA 15:1067-1077. doi:10.1261/rna.1605509

198. Pfaff J, Hennig J, Herzog F et al (2013) Structural features of Argonaute-GW182 protein interactions. Proc Natl Acad Sci 110:E3770-3779. doi:10.1073/pnas.1308510110

199. Azevedo J, Cooke R, Lagrange $T$ (2011) Taking RISCs with Ago hookers. Curr Opin Plant Biol 14:594-600. doi:10.1016/j.pbi.2011.07.002

200. Braun JE, Huntzinger E, Fauser M, Izaurralde E (2011) GW182 proteins directly recruit cytoplasmic deadenylase complexes to miRNA targets. Mol Cell 44:120-133. doi:10.1016/j.molcel.2011.09.007

201. Chekulaeva M, Mathys H, Zipprich JT et al (2011) miRNA repression involves GW182-mediated recruitment of CCR4NOT through conserved W-containing motifs. Nat Struct Mol Biol 18:1218-1226. doi:10.1038/nsmb.2166

202. Fabian MR, Cieplak MK, Frank F et al (2011) miRNA-mediated deadenylation is orchestrated by GW182 through two conserved motifs that interact with CCR4-NOT. Nat Struct Mol Biol 18:1211-1217. doi:10.1038/nsmb.2149

203. Eulalio A, Tritschler F, Büttner R et al (2009) The RRM domain in GW182 proteins contributes to miRNA-mediated gene silencing. Nucl Acids Res 37:2974-2983. doi:10.1093/nar/gkp173

204. Behm-Ansmant I, Rehwinkel J, Doerks T et al (2006) mRNA degradation by miRNAs and GW182 requires both CCR4:NOT deadenylase and DCP1:DCP2 decapping complexes. Gen Dev 20:1885-1898. doi:10.1101/gad.1424106

205. Lazzaretti D, Tournier I, Izaurralde E (2009) The C-terminal domains of human TNRC6A, TNRC6B, and TNRC6C silence bound transcripts independently of Argonaute proteins. RNA 15:1059-1066. doi:10.1261/rna.1606309

206. Zipprich JT, Bhattacharyya S, Mathys H, Filipowicz W (2009) Importance of the C-terminal domain of the human GW182 
protein TNRC6C for translational repression. RNA 15:781793. doi:10.1261/rna.1448009

207. Chekulaeva M, Filipowicz W, Parker R (2009) Multiple independent domains of dGW182 function in miRNA-mediated repression in Drosophila. RNA 15:794-803. doi:10.1261/ rna.1364909

208. Pillai RS, Bhattacharyya SN, Artus CG et al (2005) Inhibition of translational initiation by Let-7 MicroRNA in human cells. Science 309:1573-1576. doi:10.1126/science.1115079

209. Zdanowicz A, Thermann R, Kowalska J et al (2009) Drosophila miR2 primarily targets the $\mathrm{m} 7 \mathrm{G}$ pppN cap structure for translational repression. Mol Cell 35:881-888. doi:10.1016/j.molcel.2009.09.009

210. Petersen CP, Bordeleau M-E, Pelletier J, Sharp Pa (2006) Short RNAs repress translation after initiation in mammalian cells. Mol Cell 21:533-542. doi:10.1016/j.molcel.2006.01.031

211. Lytle JR, Yario Ta, Steitz Ja (2007) Target mRNAs are repressed as efficiently by microRNA-binding sites in the $5^{\prime}$ UTR as in the $3^{\prime}$ UTR. Proc Natl Acad Sci USA 104:9667-9672. doi:10.10 73/pnas.0703820104

212. Thermann R, Hentze MW (2007) Drosophila miR2 induces pseudo-polysomes and inhibits translation initiation. Nature 447:875-878. doi:10.1038/nature 05878

213. Maroney PA, Yu Y, Fisher J, Nilsen TW (2006) Evidence that microRNAs are associated with translating messenger RNAs in human cells. Nat Struct Mol Biol 13:1102-1107. doi:10.1038/nsmb1174

214. Nottrott S, Simard MJ, Richter JD (2006) Human let-7a miRNA blocks protein production on actively translating polyribosomes. Nat Struct Mol Biol 13:1108-1114. doi:10.1038/nsmb1173

215. Kiriakidou M, Tan GS, Lamprinaki S et al (2007) An mRNA m7G cap binding-like motif within human Ago2 represses translation. Cell 129:1141-1151. doi:10.1016/j.cell.2007.05.016

216. Mathonnet G, Fabian MR, Svitkin YV et al (2007) MicroRNA inhibition of translation initiation in vitro by targeting the capbinding complex eIF4F. Science 317:1764-1767. doi:10.1126/ science. 1146067

217. Chendrimada TP, Finn KJ, Ji X et al (2007) MicroRNA silencing through RISC recruitment of eIF6. Nature 447:823-828. doi:10.1038/nature05841

218. Wang B, Yanez A, Novina CD (2008) MicroRNA-repressed mRNAs contain $40 \mathrm{~S}$ but not $60 \mathrm{~S}$ components. Proc Natl Acad Sci USA 105:5343-5348. doi:10.1073/pnas.0801102105

219. Politz JCR, Zhang F, Pederson T (2006) MicroRNA-206 colocalizes with ribosome-rich regions in both the nucleolus and cytoplasm of rat myogenic cells. Proc Natl Acad Sci USA 103:18957-18962. doi:10.1073/pnas.0609466103

220. Höck J, Weinmann L, Ender C et al (2007) Proteomic and functional analysis of Argonaute-containing mRNA-protein complexes in human cells. EMBO Rep 8:1052-1060. doi:10.1038/ sj.embor.7401088

221. Vasudevan S, Tong Y, Steitz JA (2007) Switching from repression to activation: microRNAs can up-regulate translation. Science 318:1931-1934. doi:10.1126/science. 1149460

222. Mortensen RD, Serra M, Steitz JA, Vasudevan S (2011) Posttranscriptional activation of gene expression in Xenopus laevis oocytes by microRNA-protein complexes (microRNPs). Proc Natl Acad Sci USA 108:8281-8286. doi:10.1073/p nas. 1105401108

223. Kundu P, Fabian MR, Sonenberg N et al (2012) HuR protein attenuates miRNA-mediated repression by promoting miRISC dissociation from the target RNA. Nucl Acids Res 40:50885100. doi:10.1093/nar/gks148

224. Henke JI, Goergen D, Zheng J et al (2008) microRNA-122 stimulates translation of hepatitis $\mathrm{C}$ virus RNA. EMBO J 27:3300-3310. doi:10.1038/emboj.2008.244
225. Yekta S, Shih I-H, Bartel DP (2004) MicroRNA-directed cleavage of HOXB8 mRNA. Science 304:594-596. doi:10.1126/ science. 1097434

226. Karginov FV, Cheloufi S, Chong MMW et al (2010) Diverse endonucleolytic cleavage sites in the mammalian transcriptome depend upon microRNAs, Drosha, and additional nucleases. Mol Cell 38:781-788. doi:10.1016/j.molcel.2010.06.001

227. Wahle E, Winkler GS (2013) RNA decay machines: deadenylation by the Ccr4-not and Pan2-Pan3 complexes. Biochim Biophys Acta 1829:561-570. doi:10.1016/j.bbagrm.2013.01.003

228. Yamashita A, Chang T-C, Yamashita Y et al (2005) Concerted action of poly(A) nucleases and decapping enzyme in mammalian mRNA turnover. Nat Struct Mol Biol 12:1054-1063. doi:10.1038/nsmb1016

229. Zheng D, Ezzeddine N, Chen C-YA et al (2008) Deadenylation is prerequisite for P-body formation and mRNA decay in mammalian cells. J Cell Biol 182:89-101. doi:10.1083/jcb.200801196

230. Fabian MR, Sonenberg N (2012) The mechanics of miRNAmediated gene silencing: a look under the hood of miRISC. Nat Struct Mol Biol 19:586-593. doi:10.1038/nsmb.2296

231. Braun JE, Huntzinger E, Izaurralde E (2012) A molecular link between miRISCs and deadenylases provides new insight into the mechanism of gene silencing by microRNAs. Cold Spring Harb Perspect Biol. doi:10.1101/cshperspect.a012328

232. Siddiqui N, Mangus DA, Chang T-C et al (2007) Poly(A) nuclease interacts with the $\mathrm{C}$-terminal domain of polyadenylate-binding protein domain from poly(A)-binding protein. J Biol Chem 282:25067-25075. doi:10.1074/jbc.M701256200

233. Fabian MR, Mathonnet G, Sundermeier T et al (2009) Mammalian miRNA RISC recruits CAF1 and PABP to affect PABP-dependent deadenylation. Mol Cell 35:868-880. doi:10.1016/j.molcel.2009.08.004

234. Huntzinger E, Kuzuoglu-Öztürk D, Braun JE et al (2013) The interactions of GW182 proteins with PABP and deadenylases are required for both translational repression and degradation of miRNA targets. Nucl Acids Res 41:978-994. doi:10.1093/nar/ gks1078

235. Hafner M, Ascano M, Tuschl T (2011) New insights in the mechanism of microRNA-mediated target repression. Nat Struct Mol Biol 18:1181-1182. doi:10.1038/nsmb.2170

236. Houseley J, Tollervey D (2009) The many pathways of RNA degradation. Cell 136:763-776. doi:10.1016/j.cell.2009.01.019

237. Eystathioy T, Jakymiw A, Chan EKL et al (2003) The GW182 protein colocalizes with mRNA degradation associated proteins $\mathrm{hDcp} 1$ and $\mathrm{hLSm} 4$ in cytoplasmic GW bodies. RNA 9:1171-1173

238. Eulalio A, Behm-Ansmant I, Izaurralde E (2007) P bodies: at the crossroads of post-transcriptional pathways. Nat Rev Mol Cell Biol 8:9-22. doi:10.1038/nrm2080

239. Nishihara T, Zekri L, Braun JE, Izaurralde E (2013) miRISC recruits decapping factors to miRNA targets to enhance their degradation. Nucl Acids Res 41:8692-8705. doi:10.1093/nar/ gkt619

240. Béthune J, Artus-Revel CG, Filipowicz W (2012) Kinetic analysis reveals successive steps leading to miRNA-mediated silencing in mammalian cells. EMBO Rep 13:716-723. doi:10.1038/e mbor. 2012.82

241. Meijer Ha, Kong YW, Lu WT et al (2013) Translational repression and eIF4A2 activity are critical for microRNA-mediated gene regulation. Science 340:82-85. doi:10.1126/science. 1231197

242. Huang V, Li L (2012) miRNA goes nuclear. RNA Biol 9(3):269-273

243. Gagnon KT, Corey DR (2012) Argonaute and the nuclear RNAs: new pathways for RNA-mediated control of gene expression. Nucl Acid Ther 22:3-16. doi:10.1089/nat 2011.0330 
244. Weinmann L, Höck J, Ivacevic T et al (2009) Importin 8 is a gene silencing factor that targets argonaute proteins to distinct mRNAs. Cell 136:496-507. doi:10.1016/j.cell.2008.12.023

245. Nishi K, Nishi A, Nagasawa T, Ui-Tei K (2013) Human TNRC6A is an Argonaute-navigator protein for microRNAmediated gene silencing in the nucleus. RNA 19:17-35. doi:10.1261/rna.034769.112

246. Sinkkonen L, Hugenschmidt T, Filipowicz W, Svoboda P (2010) Dicer is associated with ribosomal DNA chromatin in mammalian cells. PLoS One 5:e12175. doi:10.1371/journal.pone.0012175

247. Doyle M, Badertscher L, Jaskiewicz L et al (2013) The doublestranded RNA binding domain of human Dicer functions as a nuclear localization signal. RNA 19:1238-1252. doi:10.1261/ rna.039255.113

248. Liu J, Hu J, Corey DR (2012) Expanding the action of duplex RNAs into the nucleus: redirecting alternative splicing. Nucl Acids Res 40:11270-11280. doi:10.1093/nar/gkr780

249. Ameyar-Zazoua M, Rachez C, Souidi M et al (2012) Argonaute proteins couple chromatin silencing to alternative splicing. Nat Struct Mol Biol 19:998-1004. doi:10.1038/nsmb.2373

250. Kruk JA, Dutta A, Fu J et al (2011) The multifunctional Ccr4Not complex directly promotes transcription elongation. Gen Dev 25:581-593. doi:10.1101/gad.2020911

251. Brennecke J, Stark A, Russell RB, Cohen SM (2005) Principles of microRNA-target recognition. PLoS Biol 3:e85. doi:10.1371/ journal.pbio.0030085

252. Lu M, Zhang Q, Deng M et al (2008) An analysis of human microRNA and disease associations. PLoS One 3:e3420. doi:10.1371/journal.pone. 0003420

253. Lanford RE, Hildebrandt-Eriksen ES, Petri A et al (2010) Therapeutic silencing of microRNA-122 in primates with chronic hepatitis C virus infection. Science 327:198-201. doi:10.1126/ science. 1178178

254. Janssen HLA, Reesink HW, Lawitz EJ et al (2013) Treatment of HCV infection by targeting microRNA. N Engl J Med 368:1685-1694. doi:10.1056/NEJMoa1209026

255. Davidson BL, McCray PB (2011) Current prospects for RNA interference-based therapies. Nat Rev Gen 12:329-340. doi: $10.1038 / \operatorname{nrg} 2968$

256. Boudreau RL, Davidson BL (2012) Generation of hairpinbased RNAi vectors for biological and therapeutic application. Meth Enzymol 507:275-296. doi:10.1016/B978-0-12-386509$0.00014-4$

257. Hu J, Liu J, Corey DR (2010) Allele-selective inhibition of huntingtin expression by switching to an miRNA-like RNAi mechanism. Chem Biol 17:1183-1188. doi:10.1016/j.chembiol. 2010.10.013

258. Hu J, Gagnon KT, Liu J et al (2011) Allele-selective inhibition of ataxin-3 (ATX3) expression by antisense oligomers and duplex RNAs. Biol Chem 392:315-325. doi:10.1515 /BC.2011.045

259. Fiszer A, Mykowska A, Krzyzosiak WJ (2011) Inhibition of mutant huntingtin expression by RNA duplex targeting expanded CAG repeats. Nucl Acids Res 39:5578-5585. doi:10 $.1093 /$ nar/gkr156

260. Fiszer A, Olejniczak M, Galka-Marciniak P et al (2013) Selfduplexing CUG repeats selectively inhibit mutant huntingtin expression. Nucl Acids Res 41:10426-10437. doi:10.1093/nar/ gkt825

261. Hu J, Liu J, Yu D et al (2012) Mechanism of allele-selective inhibition of huntingtin expression by duplex RNAs that target
CAG repeats: function through the RNAi pathway. Nucl Acids Res 40:11270-11280. doi:10.1093/nar/gks907

262. Liu J, Rivas FV, Wohlschlegel J et al (2005) A role for the P-body component GW182 in microRNA function. Nat Cell Biol 7:1261-1266. doi:10.1038/ncb1333

263. Meister G, Landthaler M, Peters L et al (2005) Identification of novel argonaute-associated proteins. Curr Biol 15:2149-2155. doi:10.1016/j.cub.2005.10.048

264. Jinek M, Fabian MR, Coyle SM et al (2010) Structural insights into the human GW182-PABC interaction in microRNAmediated deadenylation. Nat Struct Mol Biol 17:238-240. doi: $10.1038 / \mathrm{nsmb} .1768$

265. Wang H, Morita M, Yang X et al (2010) Crystal structure of the human CNOT6L nuclease domain reveals strict poly(A) substrate specificity. EMBO J 29:2566-2576. doi:10.1038/em boj. 2010.152

266. Morita M, Suzuki T, Nakamura T et al (2007) Depletion of mammalian CCR4b deadenylase triggers elevation of the p27Kip1 mRNA level and impairs cell growth. Mol Cell Biol 27:4980-4990. doi:10.1128/MCB.02304-06

267. Arribas-Layton M, Wu D, Lykke-Andersen J, Song H (2013) Structural and functional control of the eukaryotic mRNA decapping machinery. Biochim Biophys Acta 1829:580-589. doi:10.1016/j.bbagrm.2012.12.006

268. Wang Z, Jiao X, Carr-Schmid A, Kiledjian M (2002) The hDcp2 protein is a mammalian mRNA decapping enzyme. Proc Natl Acad Sci USA 99:12663-12668. doi:10.1073/pnas.192445599

269. Chu C, Rana TM (2006) Translation repression in human cells by microRNA-induced gene silencing requires RCK/p54. PLoS Biol 4:e210. doi:10.1371/journal.pbio.0040210

270. Fenger-Grøn M, Fillman C, Norrild B, Lykke-Andersen J (2005) Multiple processing body factors and the ARE binding protein TTP activate mRNA decapping. Mol Cell 20:905-915. doi:10.1016/j.molcel.2005.10.031

271. Ozgur S, Chekulaeva M, Stoecklin G (2010) Human Pat1b connects deadenylation with mRNA decapping and controls the assembly of processing bodies. Mol Cell Biol 30:4308-4323. doi:10.1128/MCB.00429-10

272. Jin P, Zarnescu DC, Ceman S et al (2004) Biochemical and genetic interaction between the fragile $\mathrm{X}$ mental retardation protein and the microRNA pathway. Nat Neurosci 7:113-117. doi: $10.1038 / \mathrm{nn} 1174$

273. Muddashetty RS, Nalavadi VC, Gross C et al (2011) Reversible inhibition of PSD-95 mRNA translation by miR-125a, FMRP phosphorylation, and mGluR signaling. Mol Cell 42:673-688. doi:10.1016/j.molcel.2011.05.006

274. Lai T, Cho H, Liu Z et al (2012) Structural basis of the PNRC2mediated link between mrna surveillance and decapping. Structure 20:2025-2037. doi:10.1016/j.str.2012.09.009

275. Su H, Meng S, Lu Y et al (2011) Mammalian hyperplastic discs homolog EDD regulates miRNA-mediated gene silencing. Mol Cell 43:97-109. doi:10.1016/j.molcel.2011.06.013

276. Srikantan S, Tominaga K, Gorospe M (2012) Functional interplay between RNA-binding protein HuR and microRNAs. Curr Prot Pept Sci 13:372-379

277. Glorian V, Maillot G, Polès S et al (2011) HuR-dependent loading of miRNA RISC to the mRNA encoding the Ras-related small GTPase RhoB controls its translation during UV-induced apoptosis. Cell Death Differ 18:1692-1701. doi:10.1038/ cdd.2011.35 